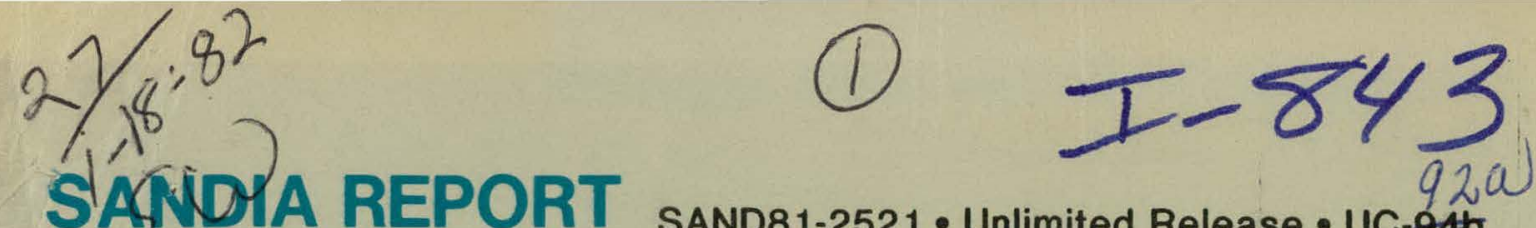

SAND81-2521 • Unlimited Release - UC-94b

Printed December 1981

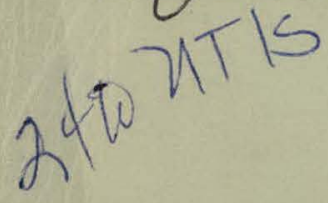

\title{
Quasi-Static Rock Mechanics Data for Rocksalt from Three Strategic Petroleum Reserve Domes
}

Ronald H. Price, Wolfgang R. Wawersik, David W. Hannum, Jeffrey A. Zirzow

\section{Prepared by}

Sandia National Laboratories

Albuquerque, New Mexico 87185 and Livermore, California 94550

for the United States Department of Energy

under Contract DE-AC04-76DP00789 


\section{DISCLAIMER}

This report was prepared as an account of work sponsored by an agency of the United States Government. Neither the United States Government nor any agency Thereof, nor any of their employees, makes any warranty, express or implied, or assumes any legal liability or responsibility for the accuracy, completeness, or usefulness of any information, apparatus, product, or process disclosed, or represents that its use would not infringe privately owned rights. Reference herein to any specific commercial product, process, or service by trade name, trademark, manufacturer, or otherwise does not necessarily constitute or imply its endorsement, recommendation, or favoring by the United States Government or any agency thereof. The views and opinions of authors expressed herein do not necessarily state or reflect those of the United States Government or any agency thereof. 


\section{DISCLAIMER}

Portions of this document may be illegible in electronic image products. Images are produced from the best available original document. 
Issued by Sandia National Laboratories, operated for the United States Department of Energy by Sandia Corporation.

NOTICE: This report was prepared as an account of work sponsored by an agency of the United States Government. Neither the United States Government nor any agency thereof, nor any of their employees, nor any of their contractors, subcontractors, or their employees, makes any warranty, express or implied, or assumes any legal liability or responsibility for the accuracy completeness, or usefulness of any information, apparatus, product, or process disclosed, or represents that its use would not infringe privately owned rights. Reference herein to any specific commercial product, process, o service by trade name, trademark, manufacturer, or otherwise, does not necessarily constitute or imply its endorsement, recommendation, or favorin by the United States Government, any agency thereof or any of their contractors or subcontractors. The views and opinions expressed herein do not not necessarily state or reflect those of the United States Government, any agency thereof or any of their contractors or subcontractors.

Priuled in the United Statos of Americe Available from

National Technical Information Service

U.S. Department of Commerce

5285 Port Royal Road

Springfield, VA 22161

NTIS price codes

Printed copy: $\$ 6.00$

Microfiche copy: A01 


\section{QUASI-STATIC ROCK MECHANICS DATA FOR ROCKSAIT FROE:}

THREE STRA:TEGIC PETROIELIS RESERVE DOIES ${ }^{*}$

Fonald H. Price, Wolfgang R. Wawersik, Davia W. Hennum: \& I f Sancia National Laboratories**

Aloucuerque, New Mexico 87185

\section{ABSTRÉCT}

Triaxial compression and extension experiments have been run on rocksalt samples from three Strategic Petroleum Reserve (SPR) domes. Seventeen quasi-static tests were loaded at mean stress rates of $.66-1.04 \mathrm{psi} / \mathrm{sec}$ $(4.5-7.2 \mathrm{kPa} / \mathrm{sec})$, confining pressures of 14.5-2000 psi (0.1-13.8 $\mathrm{HPa}$ ) anà temperatures of $22-100^{\circ} \mathrm{C}$. Eleven of the test specimens were from Bryan Mound, Texas, and three each were from Bayou Choctaw, Louisiana, and West Hackberry, Louisiana.

In general, the resulting mechanical data from the three domes are similar, and they are consistent with previously published data. Ultimate sample. strengths are directly related to confining pressure (least principal stress) and indirectly related to temperature, while auctility increases with both pressure and temperature.

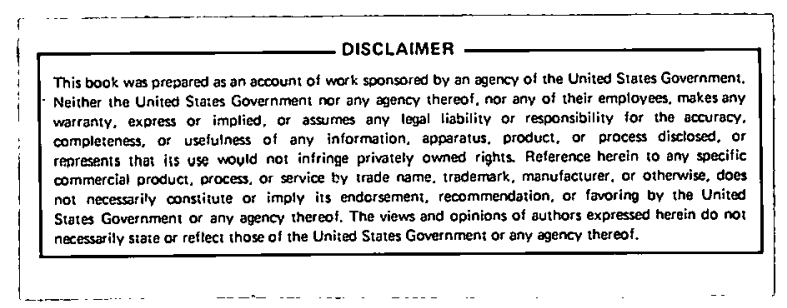

\footnotetext{
This work was supported by the U. S. Department of Energy ( Contract DE-ACO4-76-DPOO789.

* A U. S. DOE Facility.
} 
Fage

Iist of symbols and Corventions $\ldots \ldots \ldots \ldots \ldots \ldots \ldots \ldots \ldots \ldots \ldots$

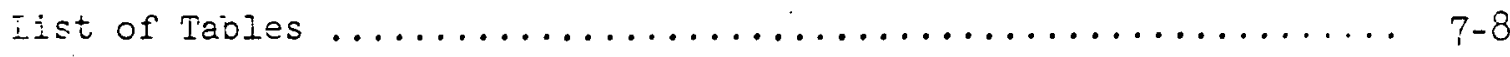

iist of Figures $\ldots \ldots \ldots \ldots \ldots \ldots \ldots \ldots \ldots \ldots \ldots \ldots \ldots \ldots \ldots \ldots \ldots \ldots$

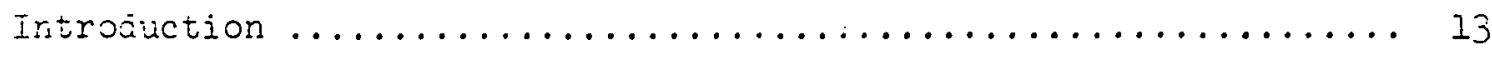

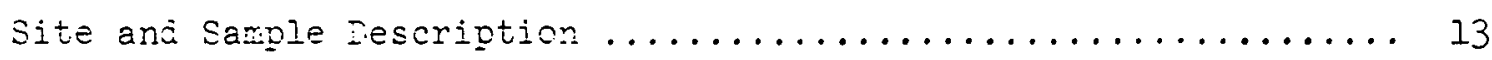

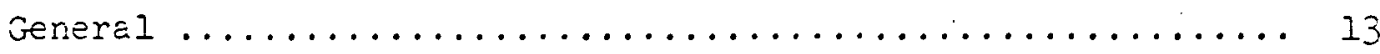

Bayou Choctan ............................... 14

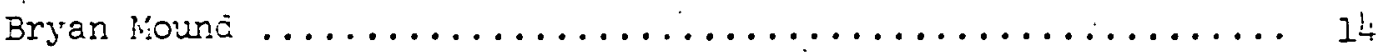

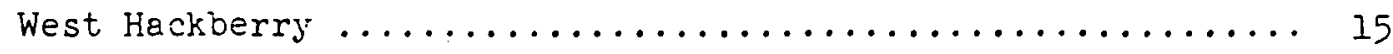

Experimental Techniques $\ldots \ldots \ldots \ldots \ldots \ldots \ldots \ldots \ldots \ldots \ldots \ldots \ldots \ldots$

Sample Preparation.$\ldots \ldots \ldots \ldots \ldots \ldots \ldots \ldots \ldots \ldots \ldots \ldots$

Testing Apparatus and Procedures ................... 15

Experimental Results $\ldots \ldots \ldots \ldots \ldots \ldots \ldots \ldots \ldots \ldots \ldots \ldots \ldots \ldots \ldots \ldots$

Test Conaitions ............................. 17

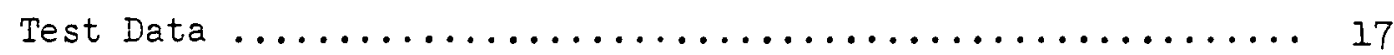

Summary and Conclusions $\ldots \ldots \ldots \ldots \ldots \ldots \ldots \ldots \ldots \ldots \ldots \ldots \ldots \ldots \ldots$






$$
\begin{aligned}
& \sigma_{1}, \sigma_{2}, \sigma_{3} \\
& e_{1}, e_{2}, e_{3} \\
& e=e_{1}+e_{2}+e_{3} \\
& \tau_{1}-\sigma_{3} \\
& e_{1}-e_{3} \\
& \left(\sigma_{1}-\sigma_{3}\right)_{m} \\
& \left(\sigma_{1}-\sigma_{3}\right)_{u} \\
& \left(e_{1}\right)_{m},\left(-e_{3}\right)_{m}, \\
& \left(e_{1}-e_{3}\right)_{m},(e)_{m} \\
& E, \nu, G, k \\
& T \\
& T, \ldots
\end{aligned}
$$

Experimental data are Eiven in both English and metric units, but are plotteo in English units consistent with SPR project requests.
True principal stresses (force, current area); compressive stresses are positive

Natural or logarithmic pripipal strains (change in length/current insh); compressive strains are positis?

Tolivi:etric strain

Priricipal stress difference or differential stress

Principal strain aifference or aifferential sirain

Maximum differential stress

Ultimate differential stress

Natural strain values corresponäing to $\left(\tau_{1}-\sigma_{3}\right)_{m}$

Elastic modili (Young 's moaulus, Poisson's ratio, shear modulius, bulk moiulus)

Temperature 




Table II: Test Iata at Maximum Deviatoric Stress ............ 20

Table III: Elastic (Unloaciing) Constants ................ 21

Table IV: Nean Elastic Constants .................... 23 


\section{I.IST OF FIGURES}

Page

Figure 1: Loading Technique.

Differential stress-time curve for sample BV 110 .

2687 deformed in compression at 250 psi and $220 . \ldots . \ldots 20$

Figure 2: Data Reproducibility.

Differential stress-greatest principal strain, dif-

ferential stress-äfferential strain and differencial

stress-volumetric strain curves for samples BC 19A/

2581 , Bi: $110 \mathrm{~s} / 2688.5$ and Bl: $1105 / 3724$ deformed in

compression at $14.5 \mathrm{psi}$ ano $22^{\circ} \mathrm{C}$

$27-29$

Figure 3: Effect of $z_{3}$ in Compression.

Iifferential stress-aifferential strain, differential

stress-volumetric strain ana aifferential strain-

volumetric strain curves for samples WH 108/2294,

WH 108/2291 and WH 108/2290 deformed in compression

at $14.5,500,2000 \mathrm{psi}$ and $60^{\circ} \mathrm{C} \ldots \ldots \ldots \ldots \ldots \ldots \ldots .32$

Figure 4: Effect of $\sigma_{3}$ in Compression.

Differential stress-differential strain, differential

stress-volumetric strain and differential strain-

volumetric strain curves for samples $\mathrm{BM} 110 \mathrm{~B} / 3728$,

$B M 110 B / 3723$ and $B$ i $110 A / 2683.5$ deformed in com-

pression at $14.5,500,1500$ psi and $100^{\circ} \mathrm{C} \ldots \ldots . \ldots 33-35$

Figure 5: Effect of $\sigma_{3}$ and $i$ in Compression.

Differential stress-differential strain and dif-

ferential stress-volumetric strain curves for

samples BM $110 \mathrm{~A} / 2688.5$ and $\mathrm{BM} 110 \mathrm{~B} / 3728$ deformed

in compression at $14.5 \mathrm{psi}$ and $22,100^{\circ} \mathrm{C}$; and

Bi: $110 \mathrm{~A} / 2692$ and $B$ il $110 \mathrm{~A} / 2683.5$ deformea in com-

pression at $1500 \mathrm{psi}$ and $22,100^{\circ} \mathrm{C} \ldots \ldots \ldots \ldots \ldots . \ldots 37$

Figure 6: Effect of $\sigma_{3}$ in Extension.

Differential stress-differential strain and dif-

ferential otrcas-volumetric slraln curves for

samples $B M 110 A / 2691$ and $B M 1070 / 2512$ deformed in

extension at $250,500 \mathrm{psi}$ and $22^{\circ} \mathrm{C} \ldots \ldots \ldots \ldots . \ldots 38$.

Figure 7: Comparison of Compression and Extension.

Differential stress-differential strain and dif-

ferential stress-volumetric strain curves for sample

WH 108/2c9l àturmed in compression and BC 19A/2579

deformed in extension at $500 \mathrm{psi}$ and $60^{\circ} \mathrm{C} \ldots \ldots \ldots .40-41$

Figure 8: Ultimate differential stress-least principal stress

plots for samples deformed in compression and

extension ............................42 
Fą̧e

Figure 9: Axial strain $0 t\left(z_{1}-\tau_{3}\right)$-least principal stress plots for samins deformes in compression anö extension .......................... 43


senples defonwij in comnession and extension ..... 44

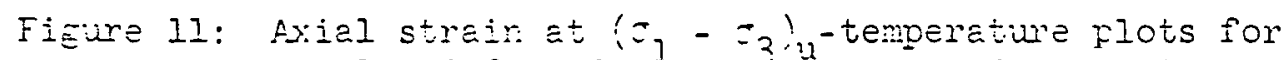

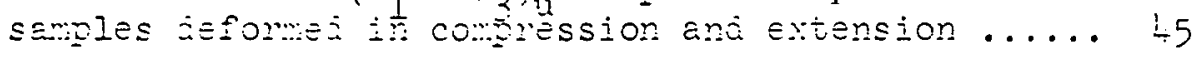




\title{
QUASI-STATIC ROCK IECHETCS IATA FOR ROCKSAIT FROU
}

THREE STRATEGIC PETROLEUR: RESERVE DORES

\begin{abstract}
Ronali H. Price, Wolfgang R. Wawersik, David W. Hannum \& Jefing. A. Zirzow Sandia National Laboratories.
\end{abstract} Albuiverue, ifex lexico 37185

\section{INTRCEUCIION}

The U. S. Stratejia Jetroleum reserve (SPR) progran is actively storing cruàe oil withir selt jores along the Texas-Louisiana coastline. Mechanical properties or rocksalt are needea to aid in the design and certification of the storage caverns. In the latest series of short-term deformation experiments, seventeen saxples from three separate SPR domes were tested under quasi-static loading conditions. These tests on Bayou Choctaw, Bryan Mound and West Hackberry core were cesignea to evaluate the effects of changes in confining pressure, tewperature arí loading concitions on mechanical behavior as a part of a lcng-range effort to (1) establish the mechanical response of rocksalt fror different SPR sites and (2) assess the fracture potential of rocksalt witrin the wells of the storage caverns.

\section{SITE ANE SAMPLE PFEPARATION}

General

Bayou Choctaw, Bryan Mound, anà West Hackberry domes are all diapiric structures formed from Jurassic salt rising into the Cenezoic seaimentary units of the Texas-Louisiana coastline along the Gulf of Mexico. The eaxplco used in mechanlcal testing are from raw core approxirately 4 in $(10.2 \mathrm{~cm})$ in diameter taken during drilling at potential caven: sites. 


\section{Bayou Choctaw (BC)}

The Bayou Chocta: come is locatec in Iberville Parisin in souti-ceritral Louisiana. The large piercement structure is almost circular in horizontal cross-section. The three $B C$ cores tested were from depths $:-2581$ it

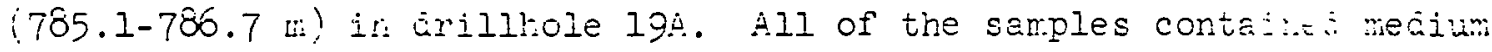
vean grain sizes of .31-.59 in (8-15 mm) with lö stanara deviations of $.16-.28$ in $(4-7 \mathrm{rm})$. Althougin no chemical anj mineralogical sample jata were available, the samples appeared to be primarily (> 90\%) halite (sodium chloride) with the predominant impurity probably being anhyarite. No preferential orientations of elongated grains or impurities were observed within any of these particular rocksalt specimens. Bryan Mound (BM)

The Bryan Mound dome occurs within Brazoria County, Texas, one halt' mile from the coast of the Gulf of Mexico. This structure is also quite circular, with a relatively flat top at an approximete aeptr of 1100 ft $(335 \mathrm{~m})$. Experimential sampies were obtained from the three arillholes 107C ( 1 sample), IIOA (6) ano 110 (4), at depth intervals of 2512 ft $(756.6 \mathrm{~m}), 2683.3-2692 \mathrm{ft}(317.0-828, \mathrm{~m})$ ari $3723-3728 \mathrm{rt}(1135-1136 \mathrm{~m})$, respectively. Grain sizes varied betiveen .039 in ( $1 \mathrm{~mm}$ ) anu 1.7 in (43 $\mathrm{rm}$ ) with an overall mean Erain size of approxiwately .33 in $(8.5 \mathrm{~mm})$. Three

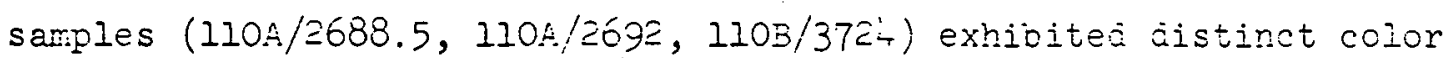
banaing at very low angles to the specimer axes (i.e., approximately vertical). These dark anj light gray anisotropies reflect variations in impurity content ${ }^{I}$. Nineralogical data from BM drillnoles 107k, 107C, $103 \equiv$ end $109 B$ reflect a halite content of at least $93 \%$, with anhydrite as the dominant impurity $(\leq 6 \%)^{1}$. 
West Hackberry (Wi)

West Hackberry dome is an irregularly shaped diapir located in Careron Parish in southwestern Louisiana. The three WH test samples were from the depth interval 2290-2294 ft $(698.0-699.2 \mathrm{~m})$ in arillrole 108 . Iarge variations in grain sizes (range: <.039-2.6 in; < 1-65 mm) vere obsemea in all samples. No mineralogical data from these samples were available; however, these cores were the darkest of the cores tested, probably reflecting a higher concentration of impurities (perhaps up to $10 \%$ anhycirite). There were no preferred orientations of grains or impurities noted.

\section{EXPERIIENTAI. TECHIIQUES}

\section{Sample Preparation}

All tests were performed on right circular cylinders. Raw cores were cut to an approximate length of $7.25-8.25$ in $(18.4-21.0 \mathrm{~cm})$ on a band saw, then experimental samples were machined to desired diameter (compression samples: 3.5 or 4.0 in $(8.9$ or $10 \mathrm{~cm}$ ); extension samples: 3.5 in $(8.9 \mathrm{~cm}))$ and a length of $7.0-8.0$ in $(18-20 \mathrm{~cm})$. The specimen enas were macnined likt and parallel to within \pm 0.001 in $( \pm .025 \mathrm{~mm})$. The cores were turned using a tungsten carbice braze tool, Carboloy AX-8, Type 883. By using this technique, samples were obtained with sharp edges anò minimel chipping or pluckine of grains.

Prior to testing, all specimens were coated with a $.01-.02$ in (.25-.5 mm) thick layer of RTV silastic (RTV 108) to fill small surface pits. Each sample was then placed between vented steel end-caps and enclosed in a flexible jacket of Viton or Neoprene.

\section{Testing Apparatus and Procedures}

All mechanical tests were conducted on two identical triaxial apparatus ${ }^{2}$ that are designed for quasi-static and creep experiments both in triaxial 
compression $\left(\sigma_{1}>\sigma_{2}=\sigma_{3}\right)$ and triaxial extension $\left(\sigma_{1}=\sigma_{2}>\sigma_{3}\right)$. These. machines are capable of testing samples of up to 4.0 ir $(10.8 \mathrm{~cm})$ in diameter and 8.25 in $(21.0 \mathrm{~cm})$ in length, at confining pressures up to $10.0 \mathrm{kpsi}(69.0 \mathrm{kPa})$ and texperatires up to "zbon $\mathrm{l}$.

Axial forces were gereratea by a cylinçrical, hyorauíc $\because \%$, and

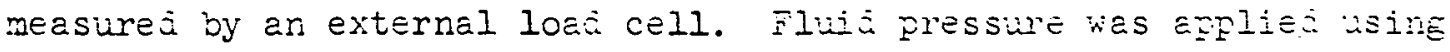
silicone fluid and was moritored wit: staniari transiucers. Axial deforwation of the sample was determined ritin tro diametrically opposed LViI's (linear variable differential transformers), by subtractine out the calibrated system deformations within the active gauge length. Lateral deformetion was determinea by means of one disk gauge ${ }^{3}$ mounted at the central dian:eter along the specimen axis or measured dilatometrically. A detuiled discussion of the techniques and data reduction proceaures is giver in an earlier report ${ }^{4}$.

Onoo the samples were jacketed and placed in the vessel, the experimental sequence was initiated. For elevated temperature/pressure tests a hydrostatic confining pressure of $500 \mathrm{psi}(3.4 \mathrm{NPa}$ ) was appliea to tre sample while the sample-vessel system was hedted. When the appropriate test temperature was reached, the fluid pressure was changed to the desirec experimental level. 'Ihe deviatorlc stress loading was then started by increasing either (1) the axial stress in a compression test or (2) the fluid pressure in an extension test. The loading paths were not smooth ramps, but a series of fast $(<2 \mathrm{sec})$ loading steps followed by four minutes of constant load. For every test, the initial stress increments were $250 \mathrm{psi}(1.7 \mathrm{MPa}$ ). This loading technique resulted in an initial stress rate of $1.04 \mathrm{psi} / \mathrm{sec}(7.17 \mathrm{kpa} / \mathrm{sec})$. Decresses in the stress rates of compression tests were caused by increases ir specimen area with radial sample strain. 


\section{EXPERII.EITAL RESIITS}

Test Conditions

The seventeen mechanical tests in tris series incluajed triaxial compression and extension experiments at mean stress rates of . $1.04 \mathrm{psi} / \mathrm{sec}$ $(4.5-7.2 \mathrm{kpa} / \mathrm{sec})$, temperatures from 22 to $100^{\circ} \mathrm{C}$ and least cin:.:2ipal stresses from 14.5 (atcospieric pressure) to $2000 \mathrm{psi}(0.1$ to $13.8 \mathrm{MPa}$ ). These ranges of pressires anc temperatures were chosen since, under these conaitions, rocksalt is pressure sensitive ana prore to macroscopic failure. Table $I$ is a matrix of experiments illustrating the specific sets of experimental conditions covered. The test/sample notation used in Table I and throughout this report consists of the following: dome, drilthole number/depth in feet (meters)/test type (C-compression, Eextension).

\section{Test Data}

The reader should note that the data presented in this report, and that referred to from earlier stucies, have not been segregated by doral site. This procedure appeared justified because the scatter in the results of samples from different locations was within that observed for samples from the same location deformed under identical conditions.

The experimental data curves are presented in Figures 1 through 7. Example plots of deviatoric stress versus time and versus axial strain are given in Figures 1 and 2A, respectively. The first graph illustrates the stepped loading path used in this test series. Figures $2 B-7$ are plots involving a combination of differential stress, differential strain and/or volumctric strain. The graphs have been chosen to exemplify (1) reprouucibility of results (Figure 2), (2) effect of $\sigma_{3}$ changes in compression (Figures 3 and 4 ), (3) effect of $\sigma_{3}$ and $T$ changes ir compression 


\section{Table I}

\section{Matrix of Experiments}

$\underline{22}$

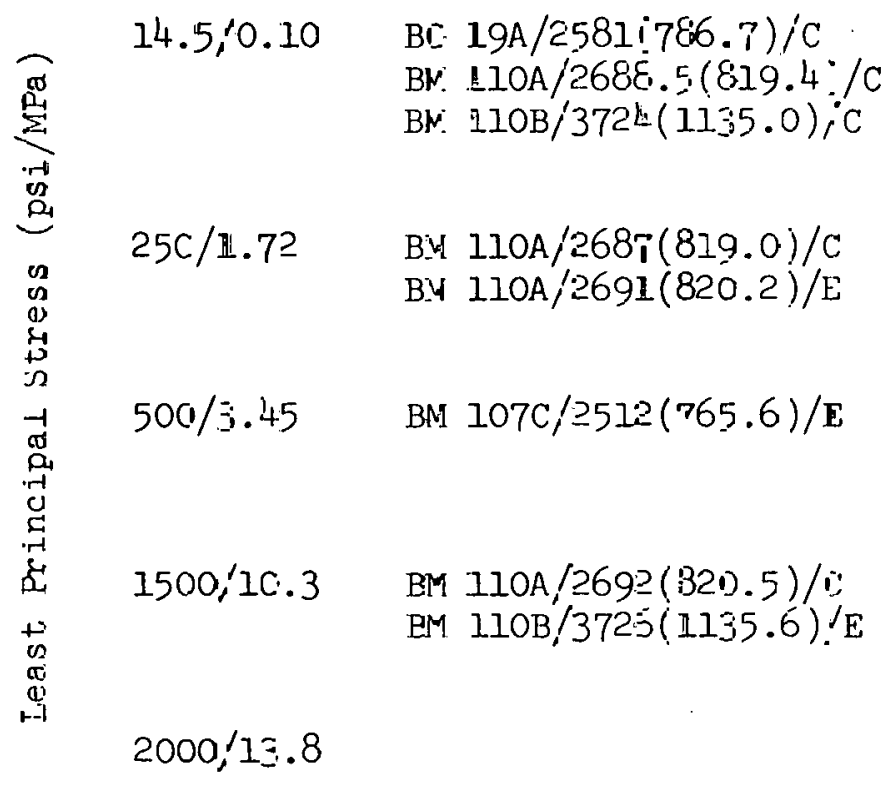

\section{$\frac{\text { Temperature }\left({ }^{\circ} \mathrm{C}\right)}{60}$}

WH $108 / 2294(699.2) / C$

BC 19A/2579(786.a)/E WH $108 / 2291(698.3) / C$

BC 19A;2575(785.11)/E WH $108,2290\left(698\right.$. C. $^{\circ} / \mathrm{C}$
BM 110A/2685(818.3), C BM 110B/3723(1134.7)/C

BM 110A/2633.5(817.9)/C 
(Figure 5), (4) effect of $\tau_{3}$ changes in extension (Figure 6) and (5) con:parison of compression and extension at constant $\sigma_{3}$ anà $T$ (Figüre 7 ). Test data at maximum aifferential stresses and the elastic constants are sumarized in Tables II and III, respectively. Six samples testề dic not reach ultimate strength (see Table II), and therefore the maxi...im value is given. The maximum cifferential stresses reported are the absolute peak stresses attained throughout the steppec loaing history of each sample. The maximum strains correspond directly to the values at the maxmium aifferential stress.

The summary plots in Figures 8-1l illustrate the effects of $\sigma_{3}$ and $T$ on differential stress and axial strain (i.e., greatest principal strain) in compression and extension. As noted on the graphs, most of the data points plotted are actual ultimate stresses and axial strains at failure. The maximum data are included for completeness, but are only lower bounds on the appropriate ultimate stresses and strains.

The experimental results presented here are consistent in trends anc̆ magnitudes with other published rocksalt data, including two earlier reports on domal rocksalt ${ }^{5,6}$. As shown in Figures 8 and 9 , rocksalt is pressure sensitive in the $14.5-2000 \mathrm{psi}(0.1-13.8 \mathrm{MPa})$ range. As expected, within the range of $\sigma_{3}$ values salt becomes distinctly stronger with increased least principal stress. Ductility (greatest principal strain to failure) is also directly related to $\sigma_{3}$. The effect of temperature on strength and ductility is shown in Figures 10 and 11 . At atmospheric pressure, no trend of temperature dependence on strength is seen, while ductility increases slightly with temperature. However, at higher pressures (500 psi; $3.45 \mathrm{MPa}$ and $1500 \mathrm{psi} ; 10.3 \mathrm{MPa}$ ), strength decreases with increasing temperature. In compression, ductility increases with temperature, 
Table II

Test Iita at Maxinum Deviatoric jউress

\begin{tabular}{|c|c|c|c|c|c|c|c|}
\hline $\begin{array}{c}\text { Test Sample } \\
\text { Drillhole/Depth-Ft(m)/ } \\
\text { Test Type } \\
\end{array}$ & $\begin{array}{c}\sigma_{3} \\
\operatorname{psi}(\mathrm{MPE})\end{array}$ & $\begin{array}{c}\mathrm{T} \\
\mathrm{O}_{\mathrm{C}} \\
\end{array}$ & $\begin{array}{l}\left(\sigma_{1}-\sigma_{3}\right) \\
k \underline{\mathrm{k} i}(\mathrm{MPa}) \\
\end{array}$ & $\begin{array}{l}\left(\mathrm{e}_{1}\right)_{\mathrm{m}} \\
\end{array}$ & $\begin{array}{c}\left(-e_{3}\right)_{m} \\
\% \\
\end{array}$ & $\left.1-e_{3}\right)^{m}$ & $\begin{array}{l}(e) \mathrm{m} \\
\% \\
\end{array}$ \\
\hline BC $19 A / 2=81(736.7) / C$ & $14.5(0.1)$ & 22 & $3.74(25.8) * *$ & 3.01 & 2.12 & 6.14 & -3.24 \\
\hline BM $110 A / 2688.5(819.4) / C$ & $14.5(0.1)$ & 22 & $2.81(19.4)^{*}$ & $\overline{2.02}$ & 3.00 & 5.02 & -3.99 \\
\hline BM $110 B / \equiv 72 L(1135.0) / \mathrm{C}$ & $14.5(0.1)$ & 22 & $4.02(27.7)^{*}$ & 3.10 & 4.51 & 7.60 & -5.91 \\
\hline BM $110 \mathrm{~A} / 2687(819.0) / \mathrm{C}$ & $250(1.72)$ & 22 & $6.05(41.7)^{*}$ & 7.49 & 2.30 & 13.1 & -3.62 \\
\hline $\mathrm{BM} 110 \mathrm{~A} / 2692(820.5) / \mathrm{I}$ & $1500(10.3)$ & 22 & $9.54(65.8 ; *$ & 31.3 & $19 . ?$ & 49.5 & -5.10 \\
\hline WH $108 / 2294 i 699.2) / C$ & $14.5(0.1)$ & 60 & $3.79\left(26.1^{\circ} *\right.$ & L. .27 & 4.47 & $3.7^{4}$ & -4.66 \\
\hline WH $108 / 2291(698.3) / \mathrm{C}$ & $500(3 .+5)$ & 60 & $5.78\left(39.9^{*} *\right.$ & -8.8 & 11.5 & 30.3 & -4.22 \\
\hline WH $103 / 2290 ;(-98.0) / \mathrm{C}$ & $2000(13.3)$ & 60 & $7.50(51.7 \%$ & 25.8 & 13.0 & 36.8 & -2.24 \\
\hline $\mathrm{BM} 11 \mathrm{OB} / 372 B(1136.2) / \mathrm{C}$ & $14.5(0.1)$ & 100 & $\Xi .74(25.8) *$ & 4.45 & 5.62 & 10.1 & -6.78 \\
\hline $\mathrm{BM} 110 \mathrm{~A} / 2685(318.3) / \mathrm{C}$ & $500(3.45)$ & 100 & $=.32(36.7) *$ & 23.6 & 15.2 & 38.9 & $-E .77$ \\
\hline BM $110 B / 3723(1134.7) / C$ & $500(3.45)$ & 100 & $5.46(37.7) *$ & 23.2 & 14.1 & 37.3 & -5.12 \\
\hline BM $11 C A / 2683.5(817.9) / C$ & $1500(10.3)$ & 100 & $6.54(45.1)$ & 32.4 & 18.3 & 50.7 & -4.80 \\
\hline BM $110 \mathrm{~A} / 2691: 820.2) / \mathrm{E}$ & $250(1.7 c)$ & 22 & $6.62(45.7)$ & 3.54 & 8.67 & 12.2 & -1.59 \\
\hline BM 107C/2512:765.6);E & $500(3.45)$ & 22 & $7.43(51.2)^{*}$ & 5.22 & 9.61 & 14.8 & 0.830 \\
\hline BM $110 B / 3726: 1135.6 ! / E$ & $1500(10.3$ & $\tilde{c 2}$ & $3.46(58.3)$ & $\lesssim .27$ & 12.1 & 18.4 & 0.421 \\
\hline $\begin{array}{l}\text { Bi } .29 A / \approx 579(786.0) / E \\
\text { BC: } 19 A / \approx 576(-85.1) / E\end{array}$ & $\begin{array}{l}500(3.45) \\
2000 i=3.81\end{array}$ & $\begin{array}{l}60 \\
60\end{array}$ & $\begin{array}{l} \pm .98(34.3) \\
5.44(44.4)\end{array}$ & $\begin{array}{l}3.49 \\
6.65\end{array}$ & $\begin{array}{l}7.29 \\
11.5\end{array}$ & $\begin{array}{l}10.3 \\
183.5\end{array}$ & $\begin{array}{l}-0.305 \\
1.465\end{array}$ \\
\hline & $200(-3.0 !$ & ou & $.4)$ & 6.65 & 11.3 & 13.5 & $\left(4 f_{3}\right.$ \\
\hline
\end{tabular}

* Actia- $u_{-}^{-}=m a t e ~ s t r e s s$ value. 
Table III

Elastic (Unloading) Constants

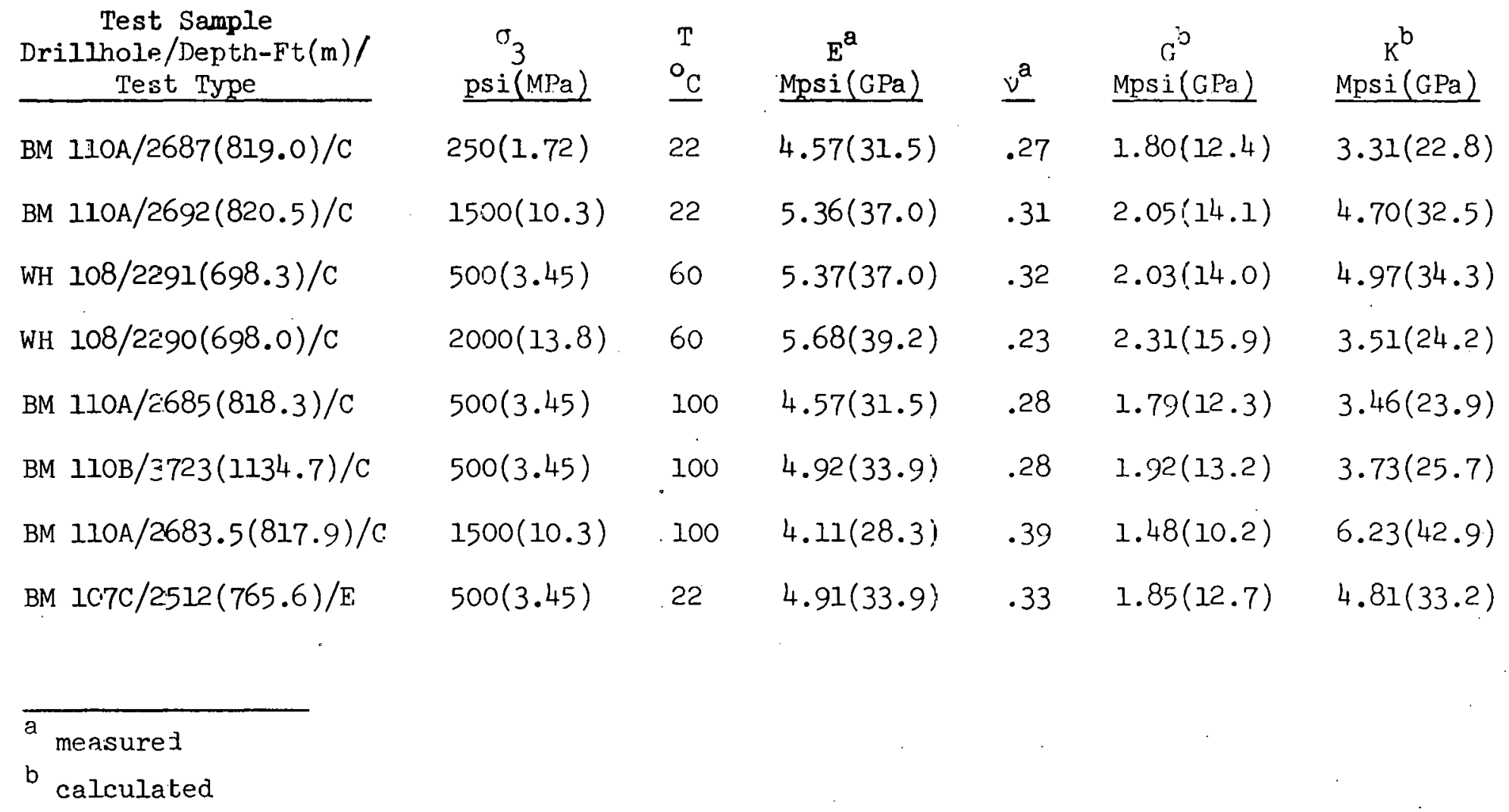


as has been previously published. Equivalent data for extension are less complete. The ultimate aifferential stresses were reached in only two of four experiments; however, the same trend of decreasing strength and increasirg auctility with temperature is suggested. Volumetri- s:min reasuremerts are also influenced by least principal stress an: inperature (see Tajle II). Zilatency at fixeà values of principal stress aifference cecreases as pressure and/or temperature is raised.

As an earlier report ${ }^{6}$ aiscussea, there are narken differences between compressior and extension results from tests at equivalent. I and $\sigma_{3}$. In general, the extension samples are approximately the same strength, but reach far less greatest principal, differential and volumetrie strains at failure than the compression samples. These contrasting results are attributed to distinctly different fuilure modes. MII extension sami les taken to failure broke suddenly along a single extension fracture (i.e., a fracture perpenaicular to $\sigma_{3}$ ); whereds, llue cumpression opccimens terifi to fail more stably by the formation of many mesoscopic (.5-3.0 in; $1.3-7.6 \mathrm{~cm})$ shear and extension cracks preceding the loss of cohesion on one or more macroscopic shear fractures. Tre volumetric strain data presentea here and from the two previous stuaies shoula prove to be significant in the development of a general fracture criterion for rocksalt.

'The elast1c (unloaking) constants obtained in this test series are presented in Table III. The Young's modull unl Poisson's ration fall within the ranges of values previously publishcd. These experimentally measured values were used to ealculate the shear and hulk moduli. By combining these data with those from two earlier reports, 5 , wean elabuic constants were delerwined for Bryon Mound, West Hackherry aric overall SPR rocksalt ( $T a b l e ~ T V$ ). The stated value of $E$ is 18 percent higher for viest 


\section{Table IV}

Mean Elastic Constants ${ }^{a}$

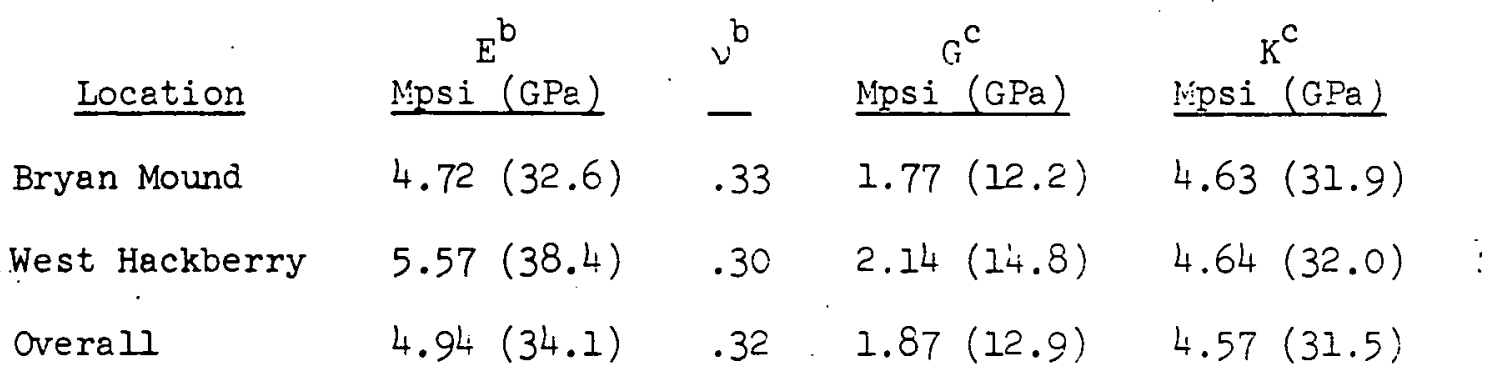

Data from references 5 and 6 anc this report.

$\mathrm{b}$ Mean of measurea values.

C Calculated fror: $E$ and $v$ values. 
Hackberry than for Bryan Mound. This result may be due to West Hackberry samples containing a greater concentration of impurities (e.g., anhyürite) than the Bryan Mound material.

\section{SUMYARY AND CONCIUSIONS}

Seventeen quasi-static experimerts on rocksalt from three SIn sites nave been presented. The test results were reproducible and consistent with previously published data. The minor variations in sample grain sizes and in composition did not appear to have an effect on strength ana behavior trenàs. As expected, specimen strength was directly related to the least principal stress and inversely related to temperature; furthermore, pressure and temperature increases resulted in larger axial strains to failure (ductility). While strengths in extension and compression were similar, ultimate strains were substantially higher in compression than in extension. 


\section{REFENENTES}

1. Bild, R. W. (1980), "Chemistry and Mineralogy of samples from the Strategic Petroleum Reserve Bryan l.ouna Site," Sanaia Irational Laboratories Report, SANE0-1258, Sancia National LaborE:aries, Albuquergue, Ni!, $50 \mathrm{p}$.

2. Wawersik, W. R. and I. Hennum (1980), "Nechanical Behavior of New Vexico Fock Salt in Triaxial Compression up to $200^{\circ} \mathrm{C}$, "J. Geophys. Res., 85, 32, 891-900.

3. Schuler, K. N. (1978), "Lateral Feformation Gauge for Rock Mechanics Testing," Exp. Mech., 18, 12 .

4. Wawersik, W. R. (1979), "Indirect Deformation (Strain) Measurements and Calibrations in Sandia Triaxial Apparatus for Testing to $250^{\circ} \mathrm{C}$," Sandia National Laboratories Report, SAN79-0114, Sandia National Laboratories, Albuquerque, Ni: $44 \mathrm{p}$.

5. Wawersik, W. R., D. W. Hannum ani H. S. Lauson (1980), "Compression anö Extension Data for Eome Salt from West Hackberry, Louisiana," Sanäia National Laboratories Report, S.AFi79-0668, Sandia National Laboratories, Albuquerque, $\mathrm{N}: 1,34 \mathrm{p}$.

6. Wawersik, W. R., D. J. Holcomb, D. W. Hannum and H. S. Lauson (1980), "Quasi-Static ana Creep Data for Dome Salt from Bryan lound, Texas," Sandia National Laboratories Report, SAND80-1434, Sanaia National Laboratories, Albuquerque, NM:, $36 \mathrm{p}$. 


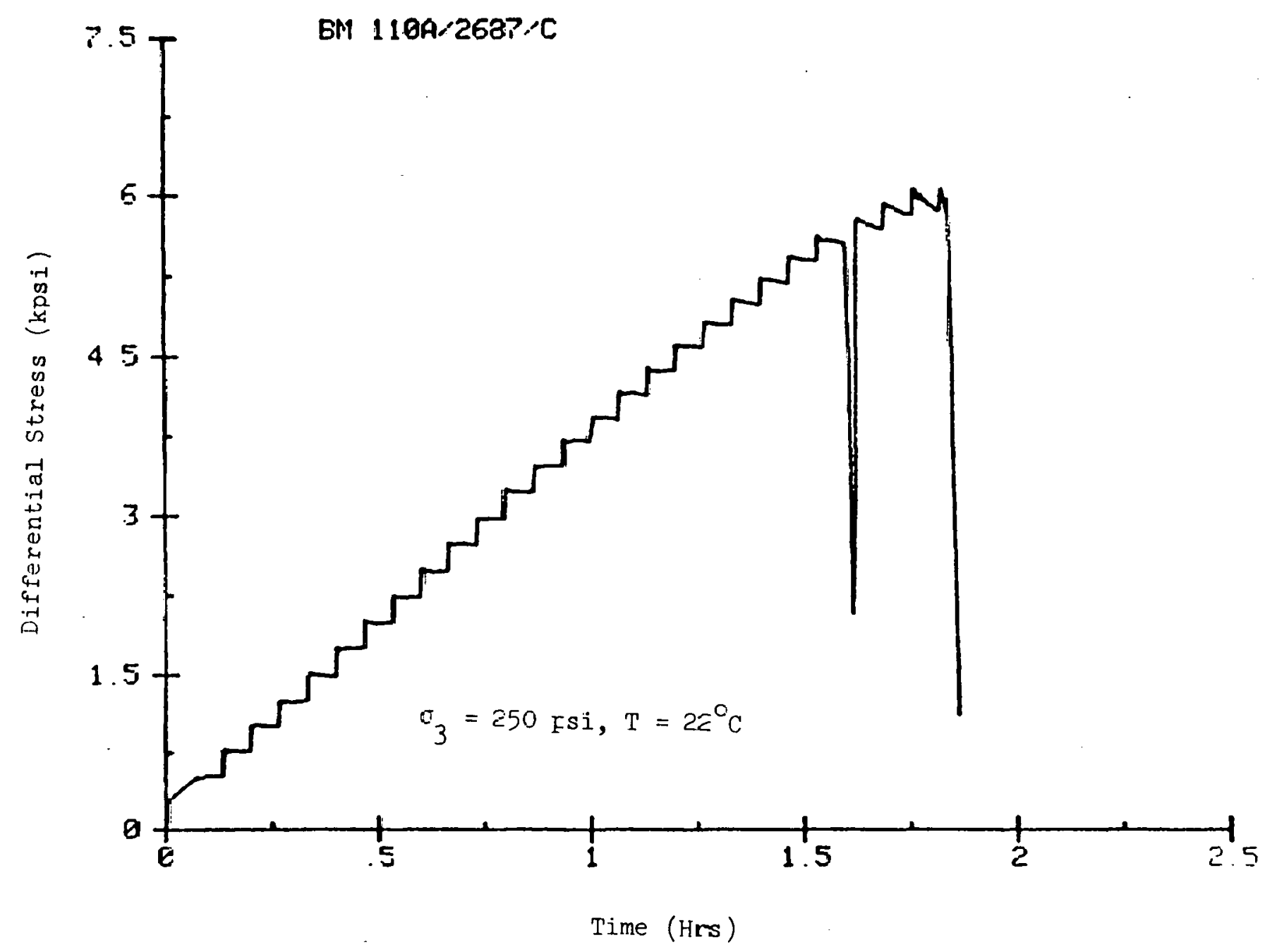

Figure 1: Dïferential stress-time cüve for sample BM 110A/2687 defcrmed in compression at 250 psi and 


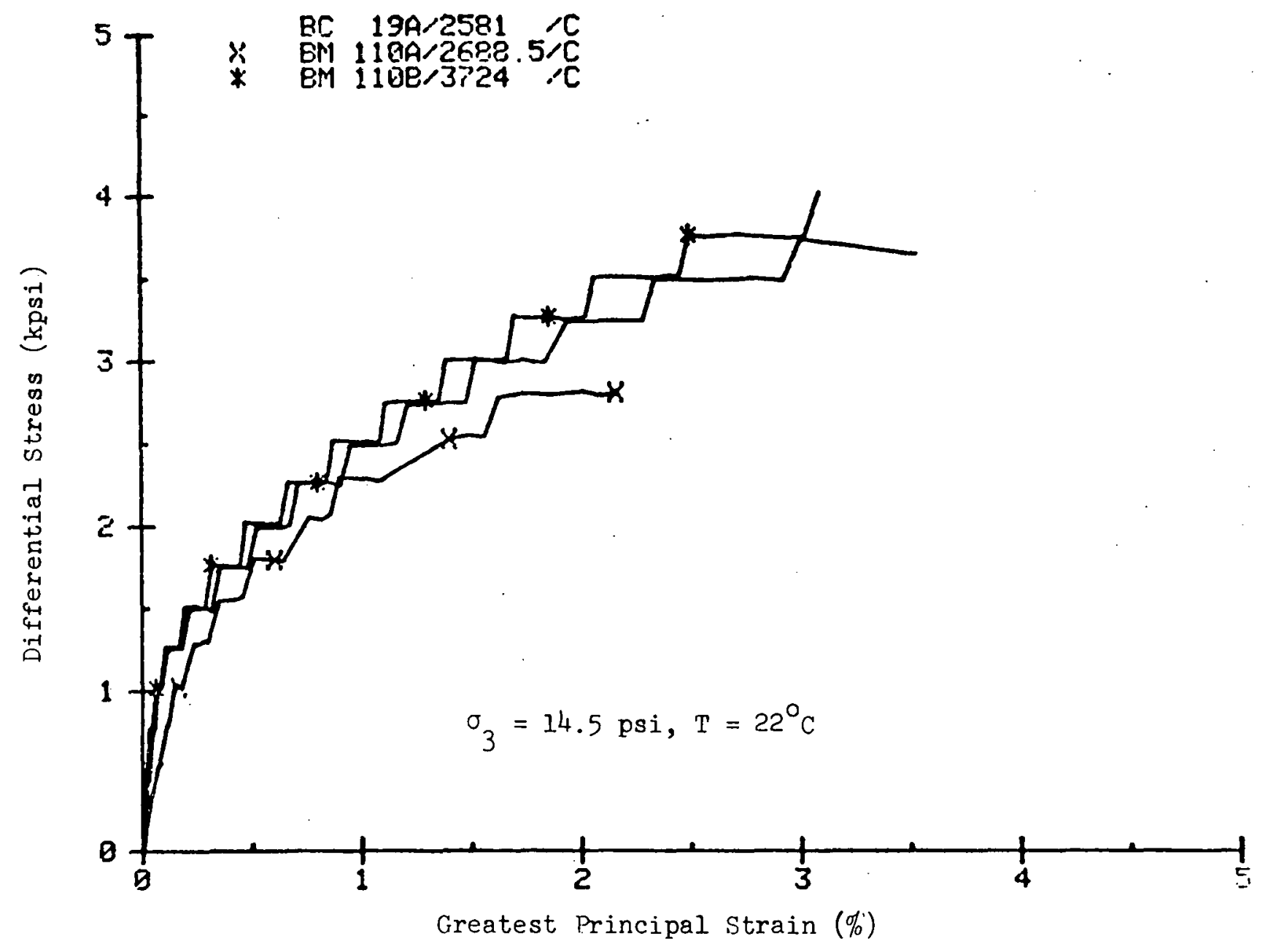

Figure 2A: Differential stress-greatest principal strain curves for samples BC 19A/2581, BM 110A/2688.5 and $\mathrm{BM} 110 \mathrm{~B} / 3724$ deformed in compression at $14.5 \mathrm{psi}$ and $22^{\circ} \mathrm{C}$. 


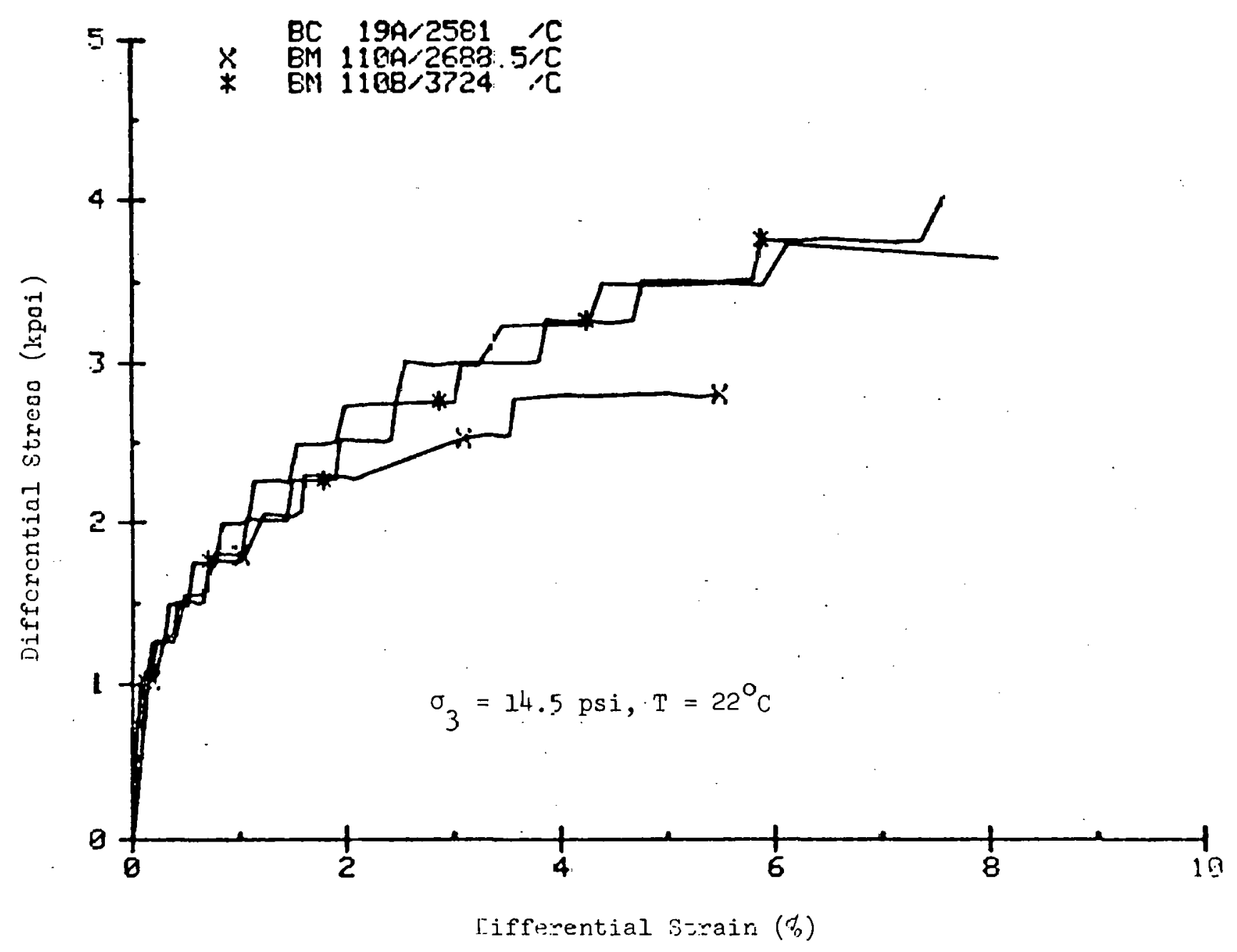

Figure 2B: Iizferential stress-differential strain curves for samples BC 19A/2581, BM $110 \mathrm{~A} / 26 \varepsilon .5 .5$ and EM $110 B / 3724$ deformed in compression at 14.5 asi and 220 . 


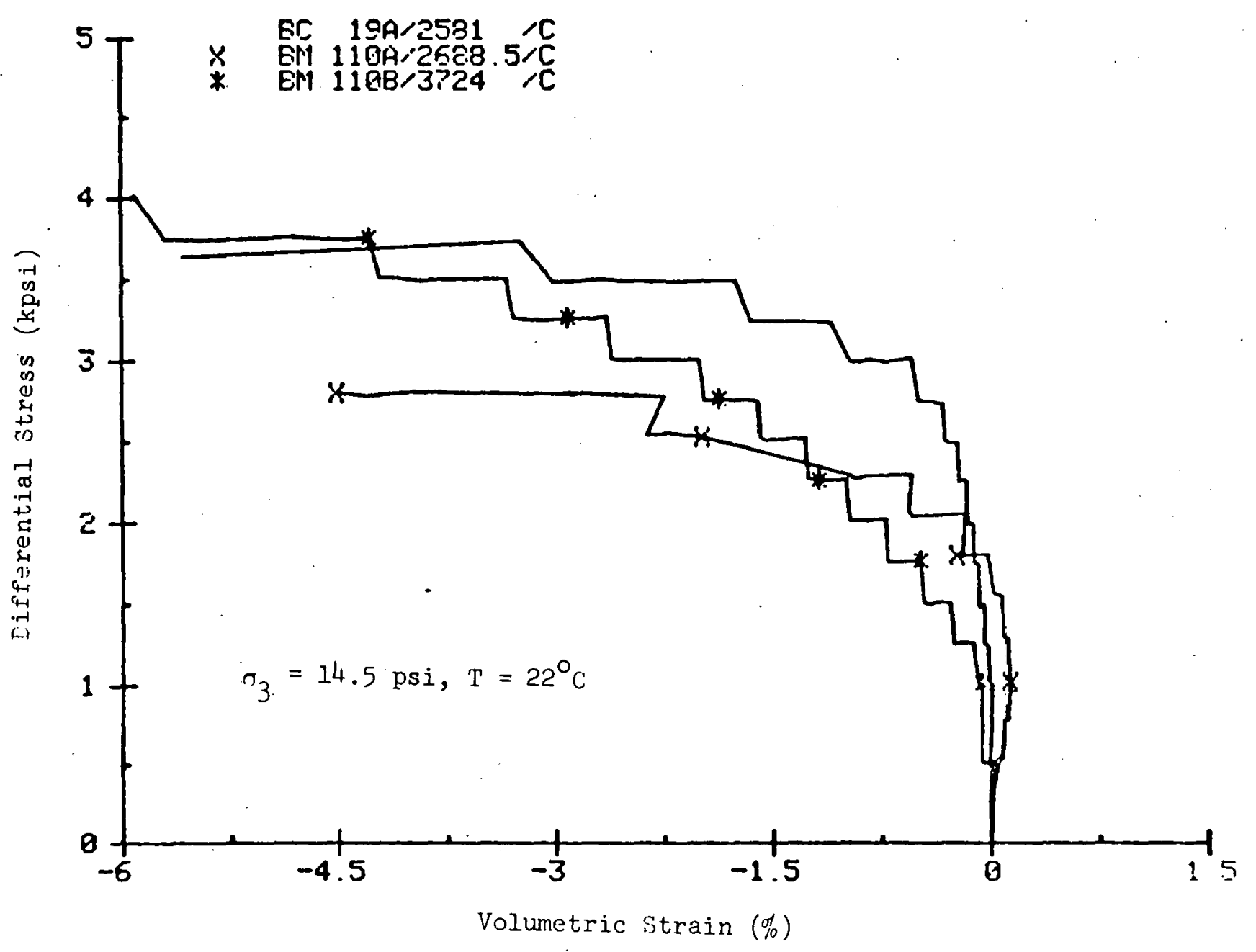

Figure 2C: Differential stress-volumetric strain curves for samples BC 19A/2581, BM 1.10A/2688.5 and $\mathrm{BM} 110 \mathrm{~B} / 3724$ deformed in compression at $14.5 \mathrm{psi}$ and $22^{\circ} \mathrm{C}$. 


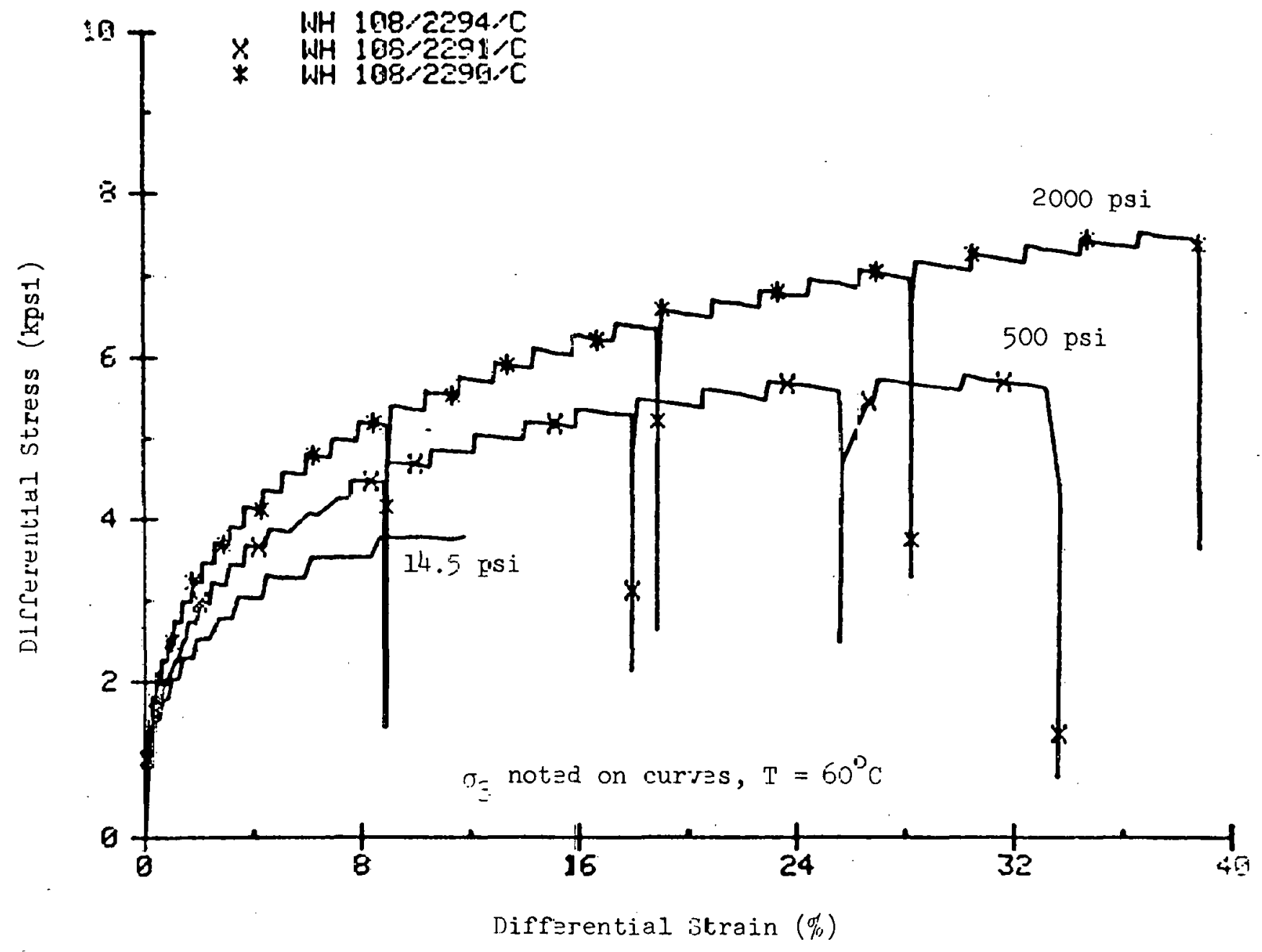

Figure 3A: Differential stress-differential staain curves for samples WH 108/2294, WH 108/22/ and WH 108/2ci90 deformed in ccmpression at 14.5, $500,2000 \mathrm{psi}$ and $60^{\circ} \mathrm{C}$. 




Figure 3B: Differential stress-volumetric strain curves for samples WH 108/2294, WH $108 / 2291$ and WH $108 / 2290$ deformed in compression at $14.5,500,2000$ psi and $60^{\circ} \mathrm{C}$. 


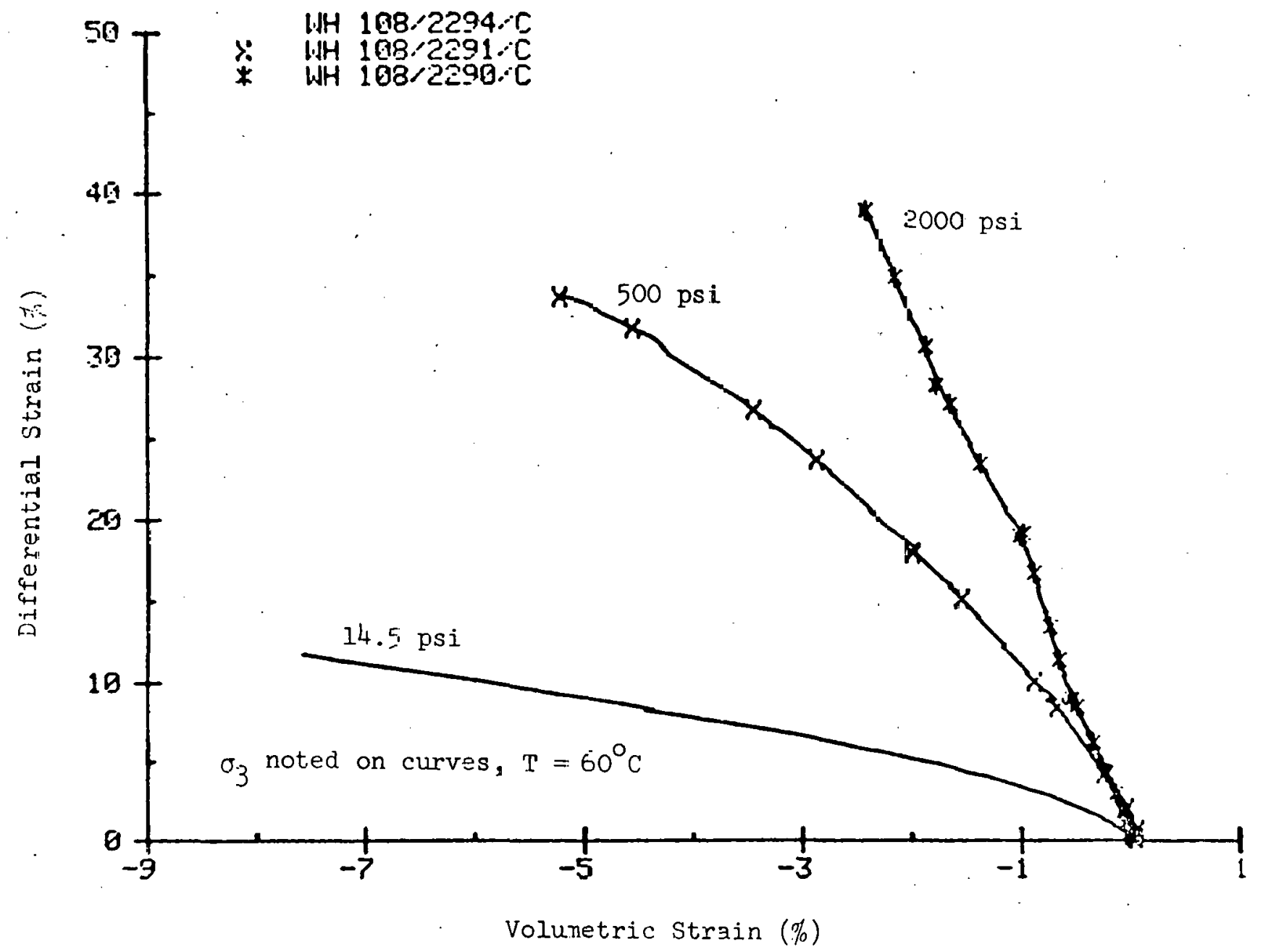

Figure 30: Jf:erential strain-volumetric strair curves for samples WF 108/2294, WH 108/2291 and WH 108/2290 deformed in compression et 14.5, 500, $2000 \mathrm{psi}$ and $60^{\circ} \mathrm{C}$. 


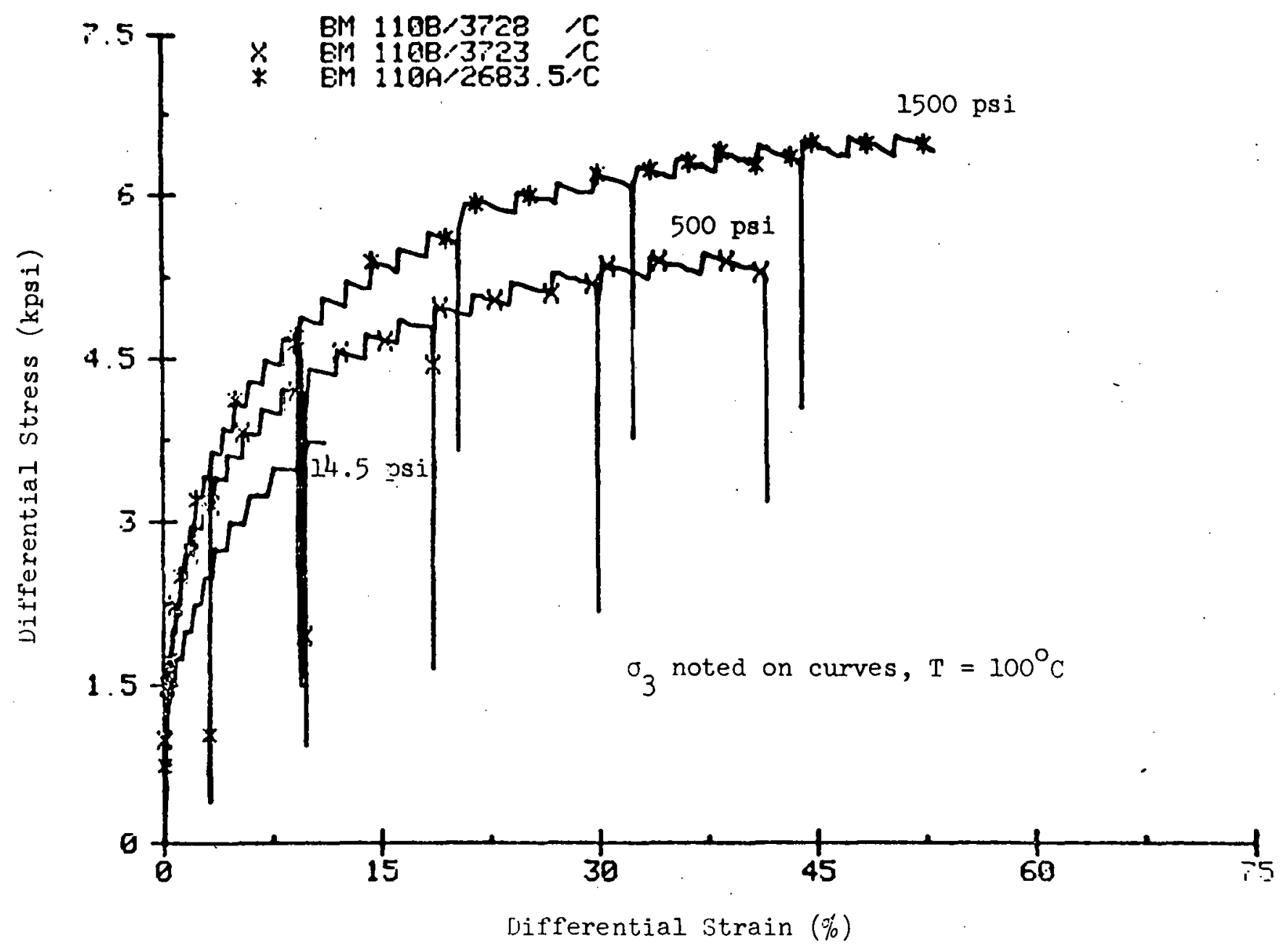

Figure 4A: Differential stress-differential strain curves for samples BM $110 \mathrm{~B} / 3728$, BM $110 \mathrm{~B} / 3723$ and $\mathrm{BM} 1 \mathrm{IOA} / 2683.5$ deformed in compression at $14.5,500,1500 \mathrm{psi}$ and $100^{\circ} \mathrm{C}$. 




Figure 43: Jifferential stress-volumetric strair. curves ror sanples BM 110B/3728, BM 110B/3723. and

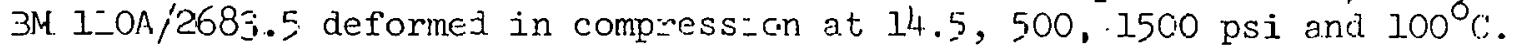






Figure 4C: Differential strain-volumetric strain curves for samples BM $110 \mathrm{~B} / 3728$, BM $110 \mathrm{~B} / 3723$ and $\mathrm{BM} 110 \mathrm{~A} / 2683.5$ deformed in compression at $14.5,500,1500 \mathrm{psi}$ and $100^{\circ} \mathrm{C}$. 


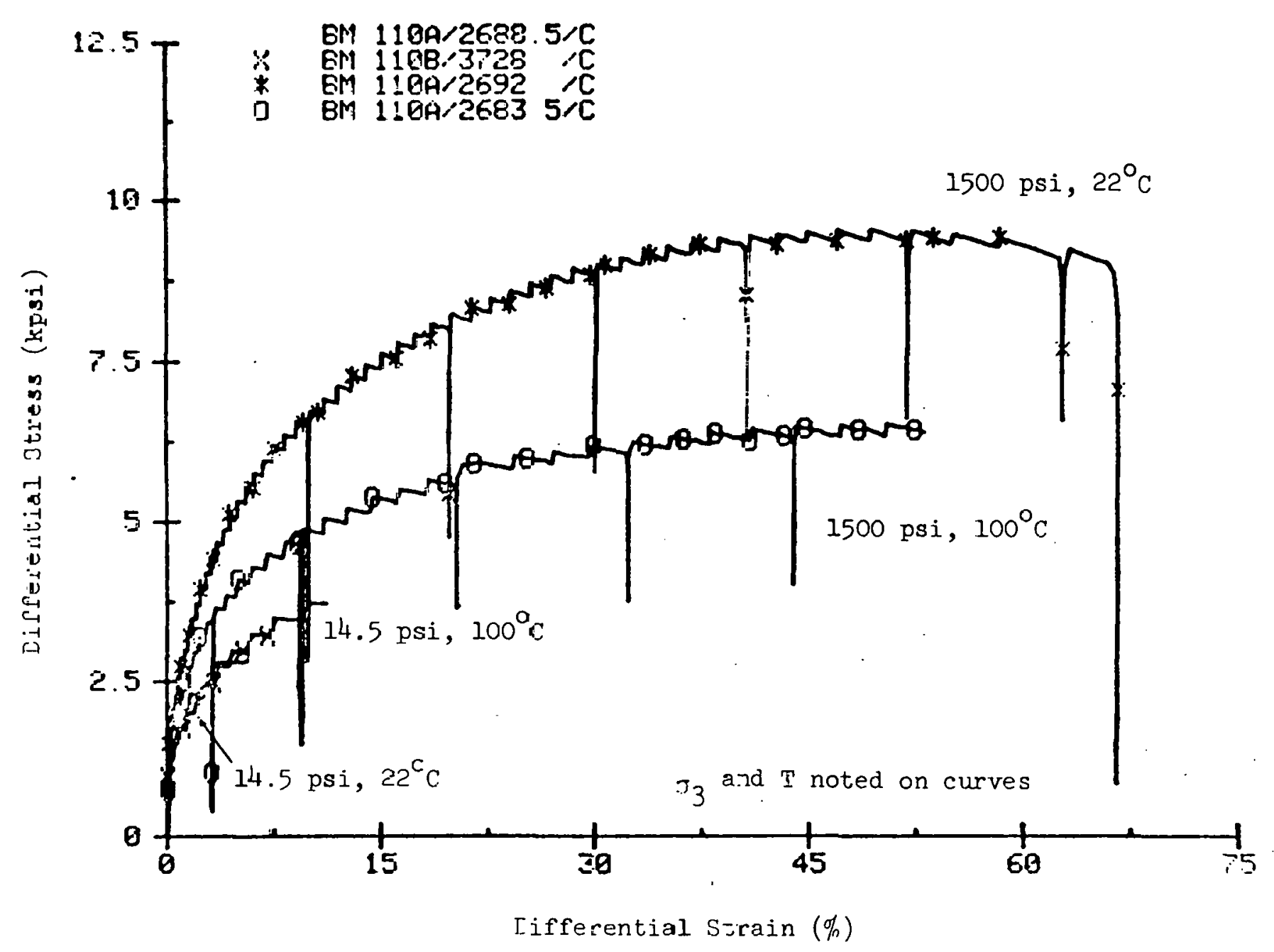

Figure 5A: Differenticl stress-differential strain curves for samples BM $110 \mathrm{~A} / 2688.5$ and $\mathrm{BM} 11 \mathrm{CB} / 3728$ deformed in compression at 14.5 $\mathrm{Fsi}$ and $22,100{ }^{\mathrm{O}} \mathrm{C}$; and $\mathrm{BM} 110 \mathrm{~A} / 2632$ and $\mathrm{BM} 110 \mathrm{~A} / 2683.5$ ceformed in compression at 1500 Fsi and $2 \tilde{c}, 103^{\circ} \mathrm{C}$. 




Figure 5B: Differential stress-volumetric strain curves for samples $\mathrm{BN} 11 \mathrm{OA} / 2688.5$ and $\mathrm{BM} 110 \mathrm{~B} / 3728 \mathrm{de}-$. formed in compression at $14.5 \mathrm{psi}$ and $22,100^{\circ} \mathrm{C}$; and $\mathrm{BM} 110 \mathrm{~A} / 2692$ and $\mathrm{BM} 110 \mathrm{~A} / 2683.5$ deformed in compression at $1500 \mathrm{psi}$ and $22,100^{\circ} \mathrm{C}$. 


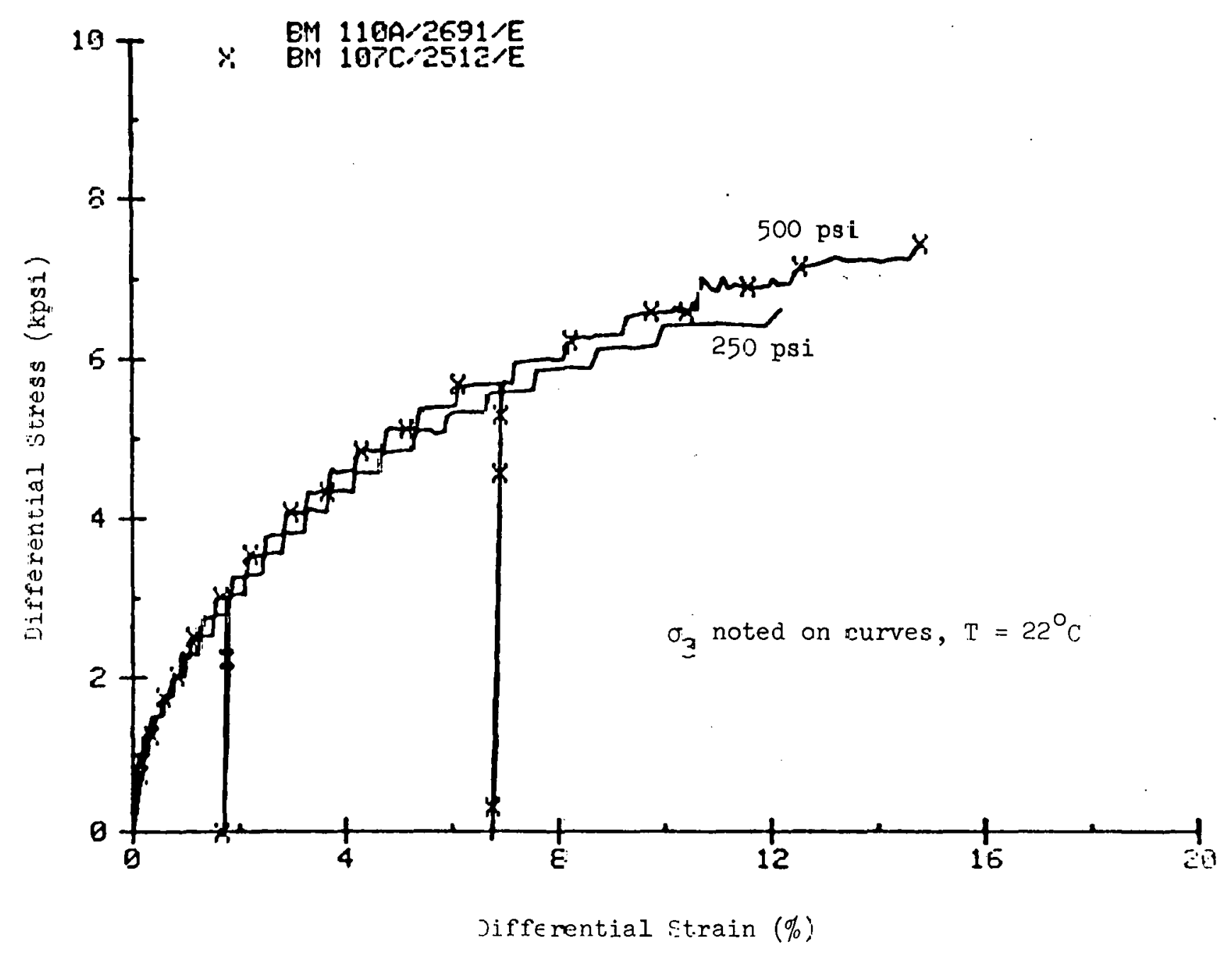

Figure 6A: Jifferential stress-differential stzein curves for sampies BM 110A/2691 and BM $1072 / 2512$ deformed in extension at $25 \mathrm{C}, 50 \mathrm{C}$ psi end $22^{\circ} \mathrm{C}$ : 


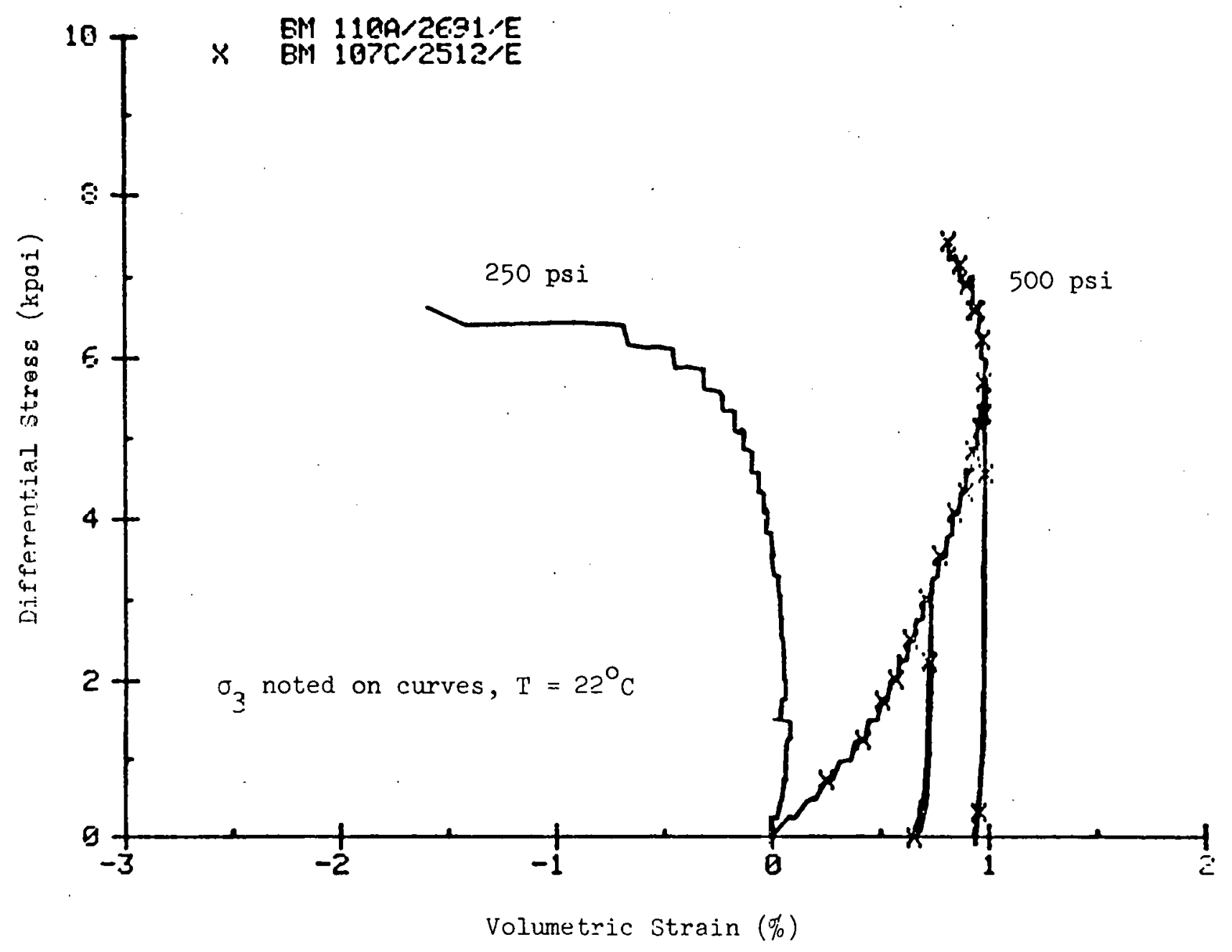

Figure 6B: Differential stress-volumetric strain curves for samples BM 110A/2691 and BM $107 \mathrm{C} / 2512$ deformed in extension at $250,500 \mathrm{psi}$ and $22^{\circ} \mathrm{C}$. 


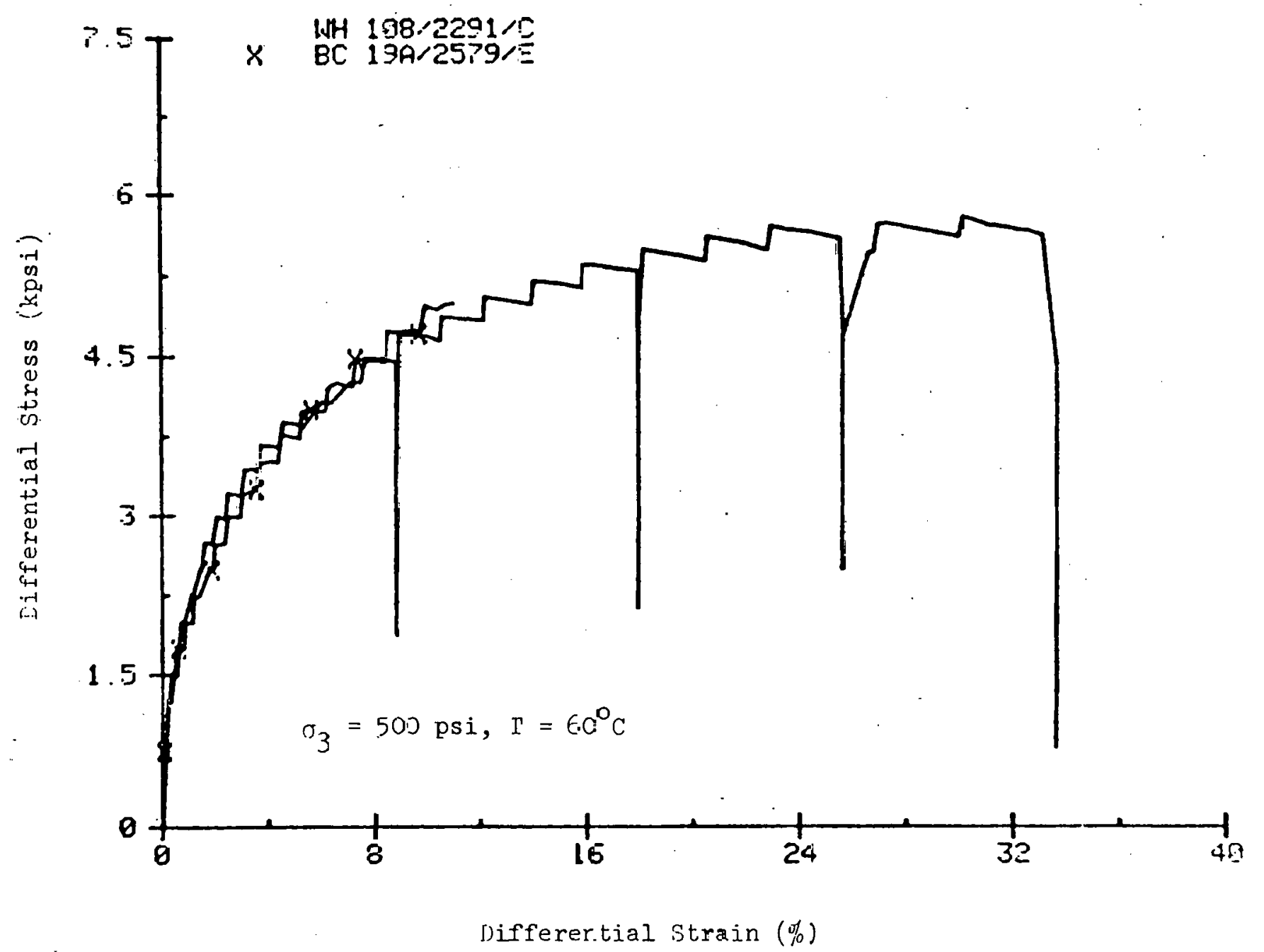

Figure 7A: Difierential stress-difierential strain curves for scmple W: 108/2291 deformed in compression and $\mathrm{BC}$ 19A/2579 deformed in extensior. at $500 \mathrm{~F} \leqslant \mathrm{i}$ and $60^{\circ} \mathrm{C}$. 


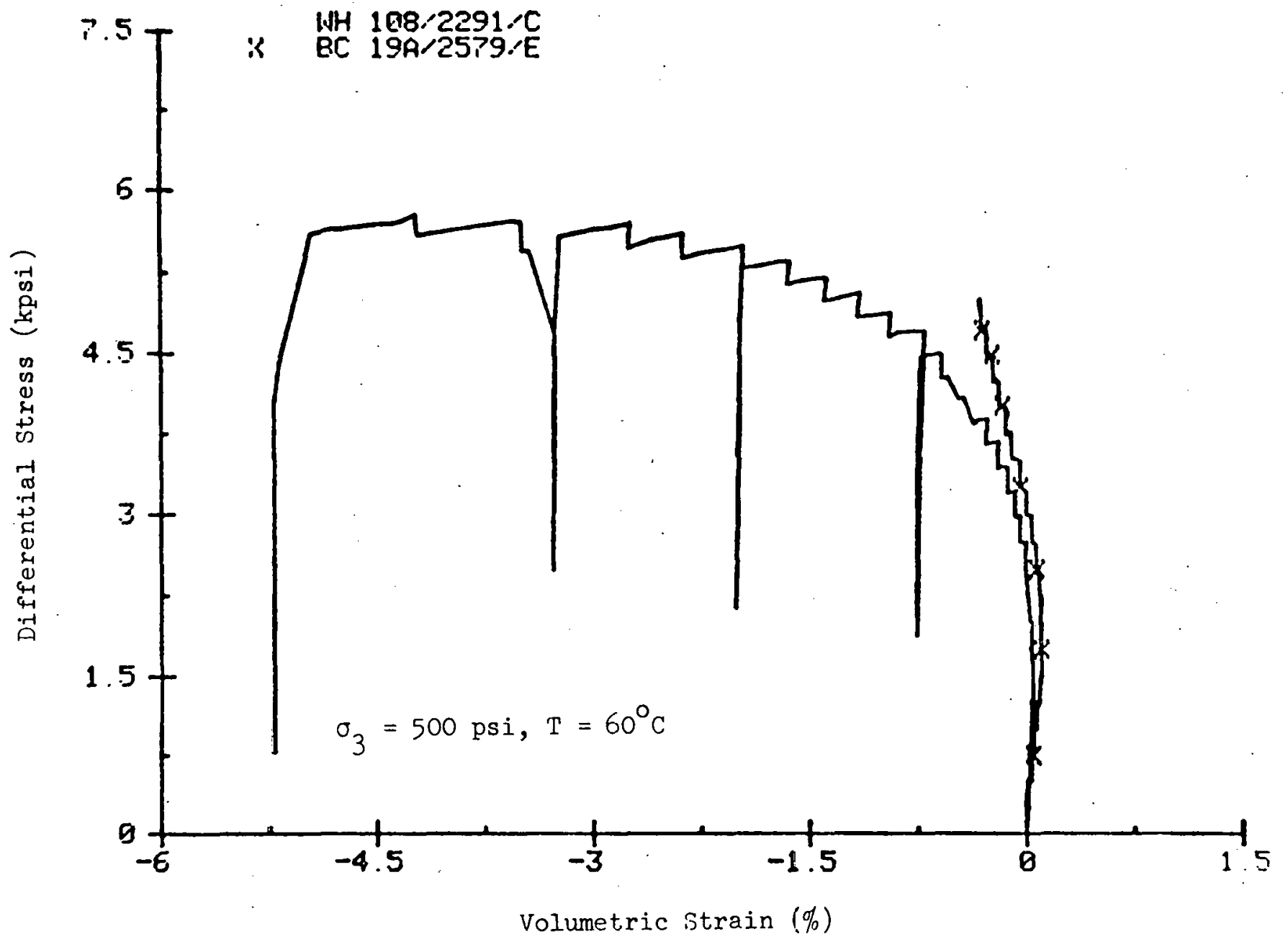

Figure 7B: Differential stress-volumetric strain curves for sample WH 108/2291 deformed in compression and $\mathrm{BC} 19 \mathrm{~A} / 2579$ deformed in extension at $500 \mathrm{psi}$ and $60^{\circ} \mathrm{C}$.

$E$ 

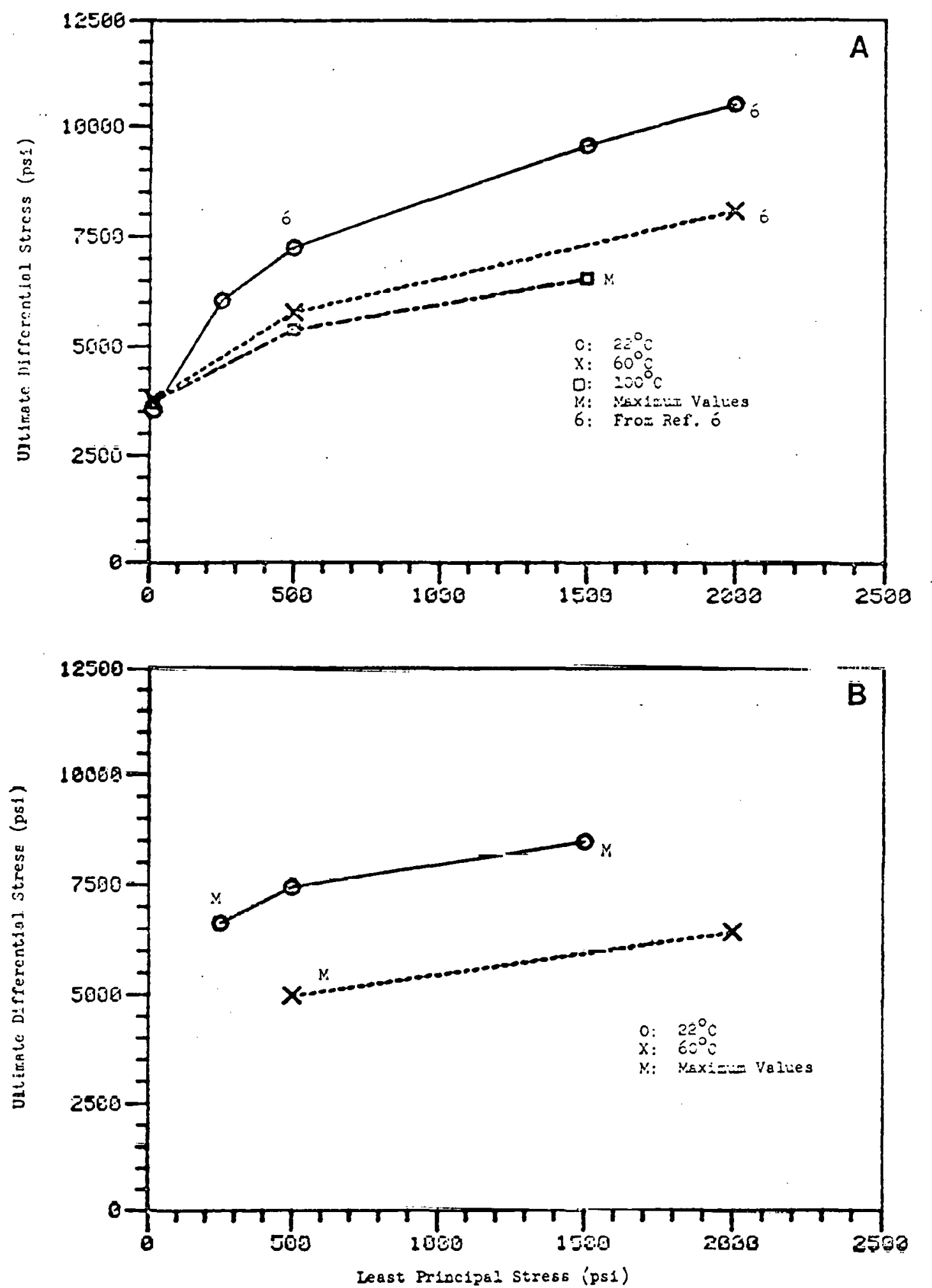

Figure 8: Ultimate differential stress-least principal stress olots for samples deformed in (A) compression anà (B) extersion. 

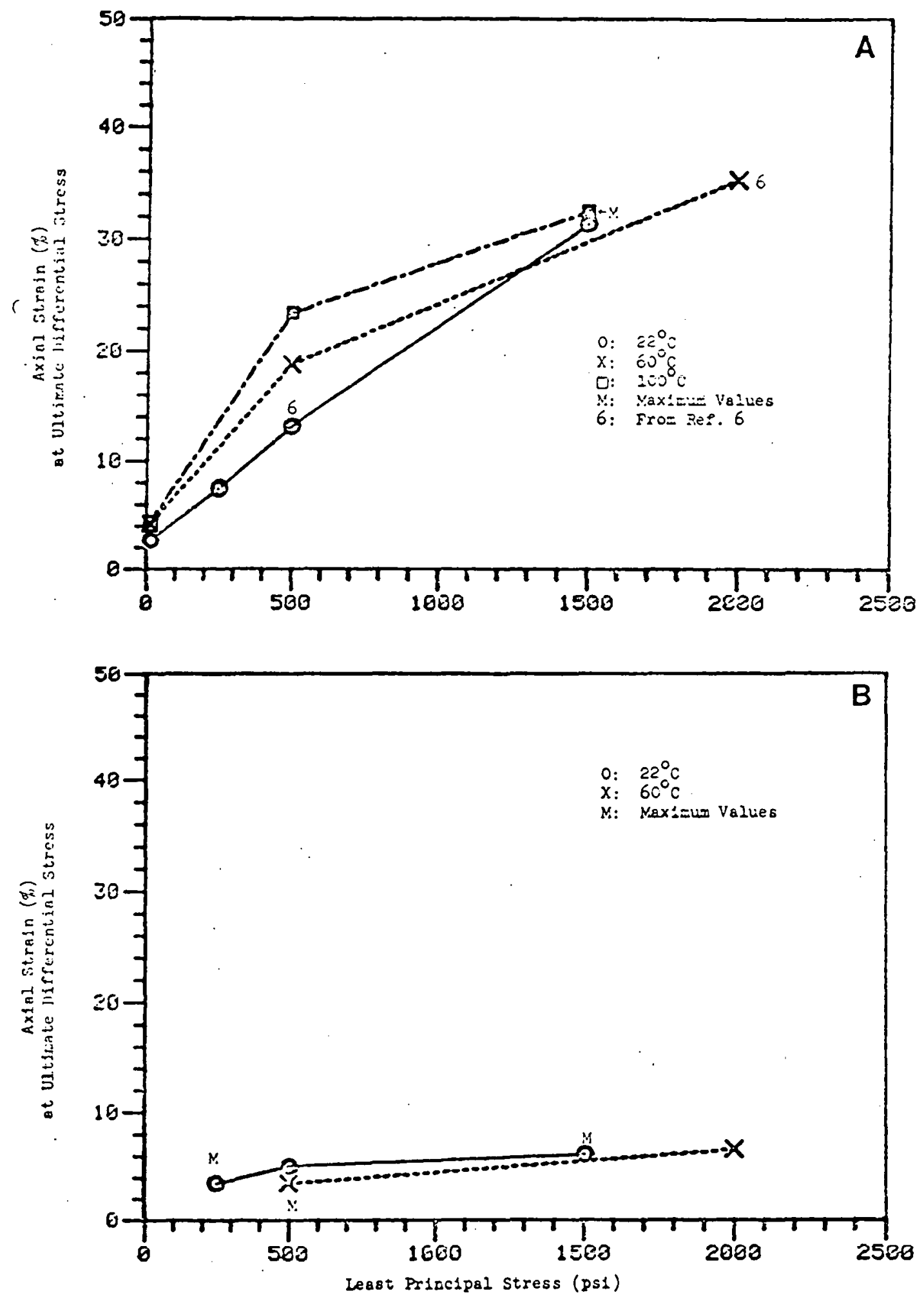

Figure 9: Axial strain at $\left(\sigma_{1}-\sigma_{3}\right)$-least principal stress plots for samples deformed in (A) compression and (B) extension. 



Figure 10: Ultimate differential stress-temperature plots for samples deformed in (A) compression and (B) extension. 

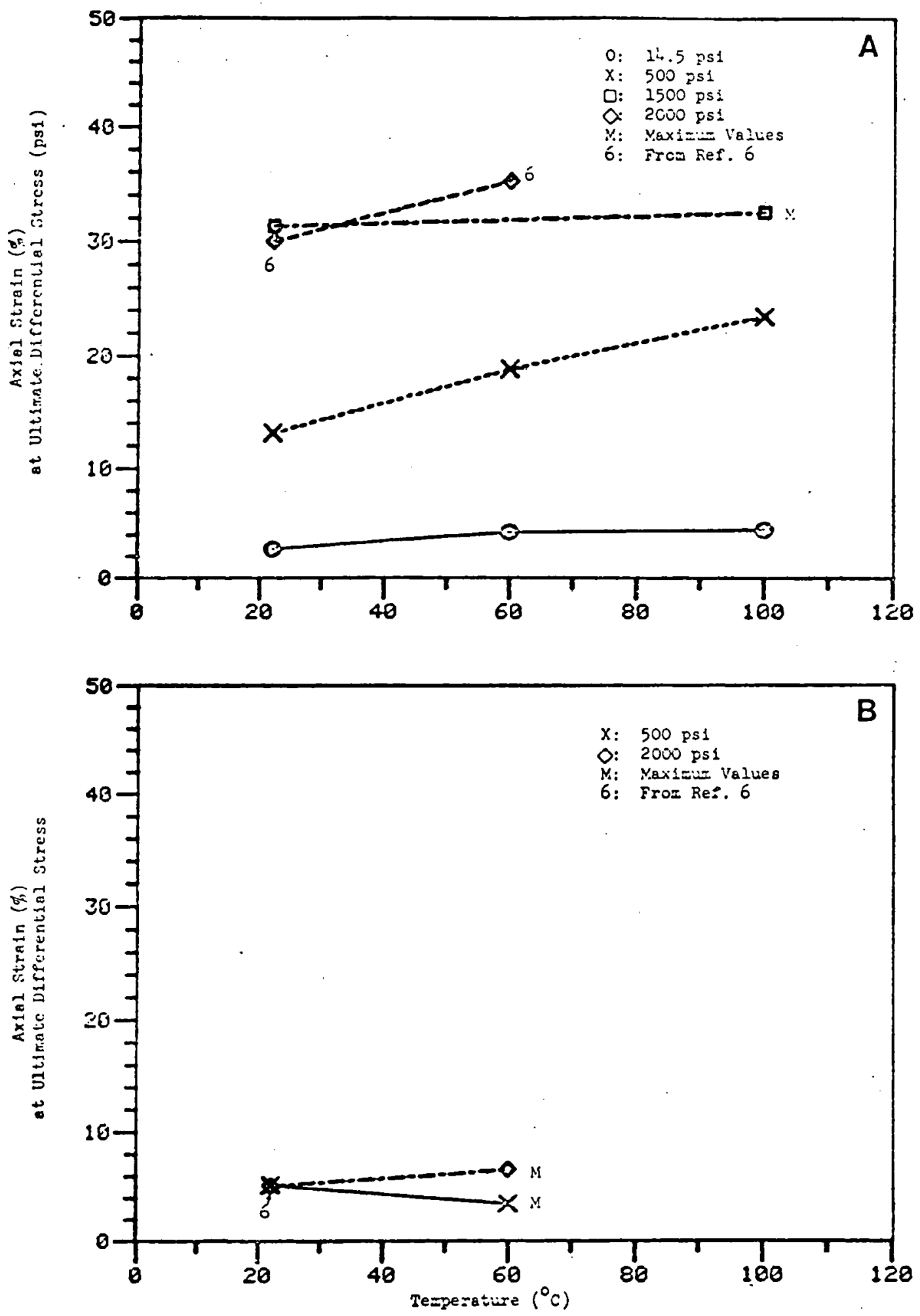

Figure.11: Axial strain at $\left(\sigma_{1}-\sigma_{3}\right)_{\mathrm{u}}$ temperature plots for samples deformed in (A) compression and (B) extension. 
US Department of Energy

Stratesic Petroleum Reserve Project l:anagement office

900 Commerce Road E'ast

New Orleans, LA 70123

A.ttn: E. E. Chapple (5)

C. C. Johnson

G. A. Stafford

C. L. Steinkamp

US Department of Energy

Strategic Petroleum Keserve 1000 Independence Averue St: wasnington, DC 20585

Attn: L. Pettis

R. Suith

Aerospace Corporation

880 Commerce Road West, Suite 300

New Orleans, LA 70123

Attn: K. Henrie

R. Merkle

Aerospace Corporation

P. 0. Box 92957

Los Angeles, CA 90009

Attr: G. F. Kuncir

Jacobs/D'Appolonia Engineers

6226 Jefferson Hwy., Suite $B$

New Orleans, IA 70123

Attn: H. Kub1cek

P. Campbell

David K. Parrish

$\mathrm{RE} / \mathrm{SPEC}$, Inc.

P. O. Box 725

Rapid City, SD 57701

John W. Handin

Center for Tectonophysics

Texas A\&M University

College Station, TX 77843

Neville L. Carter

Department of Geophysics

Texas As: University

College Station, TX 77843

4000 A. Narath

4500 E. H. Beckner

4512 I. O. Hunter
4512 R. V. liatalucci

4512 D. E. Wuson

4540 N. I. Kram:

4543 J. F. Ney

4543 R. R. Beesle?

5500 O. E. Jones

5510 D. B. Hayes

5520 T. B. Iane

5521 R. D. Kriez

5522 D. S. Preece

5530 W. Hermarn

5532 B. M. Butcher

5532 D. W. Hannum

5532 R. H. Price (15)

$553 a^{i}$ W. R. Wawersik (5)

5532 D. H. Zeuch

5532 J. A. Zirzow

3141 L. J. Erleksuil (J)

3151 W. L. Garner (3)

3154-3 C. Dalin (35) For: DOE/TIC (Unlimiteá Release)

8214 M. A. Pưuria 


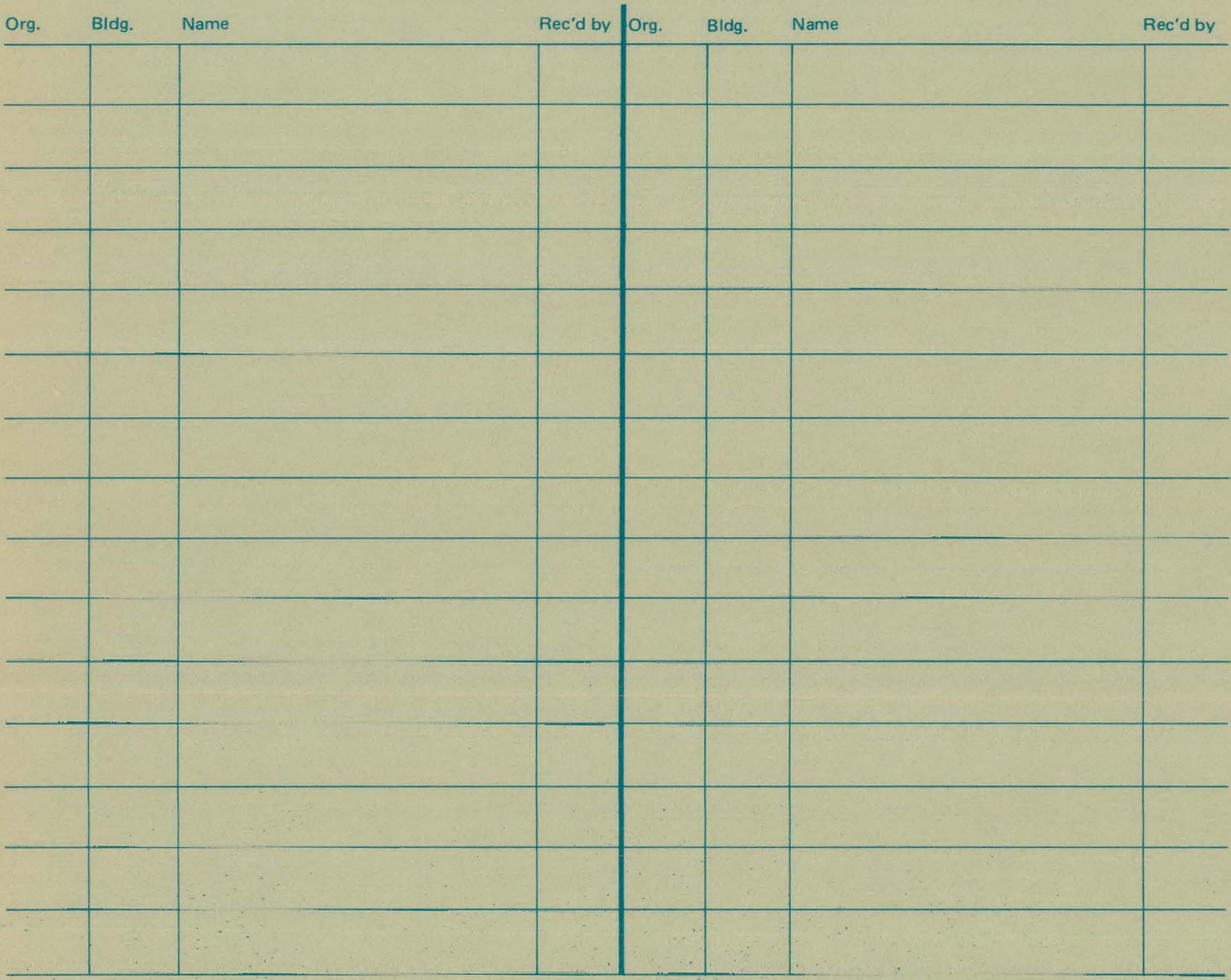

